\title{
BIBLIA I NAUKA. SIEDEM REFLEKSJI INSPIROWANYCH MYŚLĄ KS. MICHAŁA HELLERA
}

\section{Wprowadzenie ${ }^{1}$}

Relacje Biblia - nauka można rozpatrywać w dwóch wielkich kategoriach. Pierwsza to relacje między Biblią a naukami humanistycznymi i społecznymi. Chodzi głównie o historię, archeologię, filologię, antropologię (zwł. kulturową), socjologię (zwł. historyczną), literaturę porównawczą itd. Ich znaczenie dla studiów i badań biblijnych jest ogromne. Druga kategoria to relacje Biblii z naukami matematyczno-przyrodniczymi, takimi jak fizyka, kosmologia, biologia, neuronauki itp. Tu interakcja $\mathrm{z}$ danymi biblijnymi jest niewielka, jednak w powszechnym odbiorze to na tym polu najczęściej Biblia konfrontowana jest z nauką. Osobiście interesuję się głównie relacjami z tej pierwszej kategorii, ale $\mathrm{z}$ uwagi na tematykę sympozjum poświęconą myśli ks. Michała Hellera, w tym artykule poruszę wybrane kwestie z drugiej kategorii: styku Biblii i nauk przyrodniczych.

Współczesna wiedza naukowa o człowieku i świecie rzuca wiele nowego i cennego światła na utrwalone prawdy biblijne i teologiczne, które domagają się ponownego przemyślenia i naświetlenia w kontekście aktualnego obrazu świata. Teologia biblijna nie dogmatyzuje jednego ustalonego obrazu rzeczywistości - a przynajmniej nie powinna - ale zostawia te kompetencje nauce i na jej wynikach opiera się w interpretacji doświadczenia Boga, który objawia się człowiekowi.

1 Artykuł stanowi poszerzoną wersję wystąpienia na konferencji: Bóg i naukaVII Ogólnopolska Interdyscyplinarna Konferencja ,,Wokót myśli Michała Hellera”, która odbyła się w dniach od 3 do 5 XII 2015 r. w Krakowie na Uniwersytecie Papieskim Jana Pawła II. 
Trzeba ciągle podkreślać, na czym polega istota natchnienia i objawienia biblijnego, by chronić siebie od myślenia magicznego oraz fundamentalistycznego na temat prawdy zawartej w Biblii. Jeśli teologia biblijna chce pozostać wiarygodna, powinna konfrontować swe ustalenia z tym, co dziś wiemy o człowieku i świecie. Jak to robić? Warto budować nowe modele, które uzgadniają wiedzę przyrodniczą z danymi teologicznymi wywiedzionymi z Biblii, i nowe języki, które paralelnie do języka nauki ujmują rzeczywistość w jej odniesieniu do Boga. Badania nauk przyrodniczych potwierdzają, że światem i jego prawami rządzi szeroko rozumiana ewolucja, rozwój. Jest to globalna teoria unifikująca nauki przyrodnicze - nie tylko biologię i fizykę która nie ma alternatywy w naukowym poznawaniu świata, trzeba ją zatem uwzględnić. Jeśli pozostaniemy przy statycznym obrazie, który z perspektywy dzisiejszej wiedzy wydaje się przestarzały, wówczas teologia będzie stopniowo tracić swą wiarygodność, a Biblia stanie się pomnikiem starożytnej literatury i niczym więcej.

Celem mojego artykułu jest ukazanie kilku obszarów, na których wyniki egzegezy i teologii biblijnej powinny być na nowo skonfrontowane z najnowszymi odkryciami nauki na temat świata, przyrody, ewolucji, człowieka, mózgu, wolnej woli, psychologii i moralności. Przyświeca mi refleksja św. Augustyna, który pisał, że jeśli tekst biblijny wydaje się pozostawać w sprzeczności z dobrze ustaloną prawdą naukową, to należy wówczas poddać ten tekst reinterpretacji metaforycznej. Ksiądz i filozof Ernan McMullin, komentując tę hermeneutyczną zasadę św. Augustyna, lekko ją przeformułowuje: „Jeśli zaistnieje pozorny konflikt między dobrze ustaloną teorią naukową i jakimś punktem doktryny chrześcijańskiej, wtedy chrześcijanin powinien z dużą starannością przeanalizować racje przemawiające za tą doktryną". ${ }^{2}$ Jak widać, nacisk położony jest na dobrze ustalone naukowe prawdy, bowiem nie chodzi o „ściganie” nowych odkryć i dostosowywanie na siłę teologii do wszelkich nowinek ze świata nauki. Nie jest to zresztą możliwe, nauka rozwija się zbyt szybko.

2 E. M c Mulli n, Ewolucja i stworzenie, tłum. J. R o d z én, Copernicus Center, Kraków 2014, s. 3. 
Chodzi o uzgodnienie zasadniczego obrazu świata i człowieka, jaki wyłania się z badań rozumowych z tym, który wyłania się z tekstów objawionych i tradycyjnego nauczania Kościoła, aby nie tworzyć podwójnej, niespójnej i schizofrenicznej rzeczywistości. Historia uczy teologię, że trzeba być ostrożnym w dogmatyzowaniu takiego czy innego obrazu świata, gdyż dynamiczny rozwój nauk przynosi wciąż nowe odkrycia, które niejednokrotnie stawiają statyczną, pryncypialną w myśleniu religijność w trudnym położeniu, jak było choćby za czasów Kopernika, Galileusza, Darwina czy jak jest nierzadko dziś. Trzeba więc umiejętnie ze skarbca ludzkiej myśli wydobywać i łączyć rzeczy stare i nowe (por. Mt 13,51).

\section{Czy pojęcie duszy jest nam jeszcze potrzebne?}

Jednym z ważnych zagadnień na styku Biblii i nauki jest temat duszy ludzkiej. Chodzi o biblijne, filozoficzno-teologiczne i naukowe pojęcie duszy. Te trzy podejścia nie są tożsame. Dusza w rozumieniu filozoficzno-teologicznym - zwłaszcza od czasów Kartezjusza - to niematerialna rozumna forma ciała (anima forma corporis) o statusie wyższym niż materia. Odpowiada za takie elementy naszego człowieczeństwa, jak samoświadomość, wola, rozumność czy osobowość. W tradycyjnej teologii to, co nas odróżnia od świata zwierząt, to właśnie racjonalna i nieśmiertelna dusza. Takie rozumienie duszy rodzi dziś dwa poważne problemy. Po pierwsze, współczesne nauki o człowieku opowiadają się przeciwko definiowaniu duszy za pomocą fenomenów biologiczno-psychicznych. Po drugie, także biblijna antropologia nie zawiera tak zdefiniowanego pojęcia duszy i jest, paradoksalnie, bliższa współczesnym rozstrzygnięciom naukowym niż tradycyjne, wywiedzione ze średniowiecza i renesansu rozwiązania filozoficzne.

Współczesna nauka - mam głównie na myśli dynamicznie rozwijające się nauki o mózgu (neuronauki), biologię, psychologię, kognitywistykę, genetykę i stosunkowo nową dziedzinę, jaką jest embodied cognition („ucieleśnienie”) - odrzuca wyżej zdefiniowane pojęcie duszy, jednak nie ze złośliwości czy chęci atakowania wiary. Po prostu 
z naukowego punktu widzenia funkcje, jakie dawniej przypisywano duszy - a więc samoświadomość, rozumność, wolna wola, charakter, jaźń, umysł, pamięć itp. - są dziś dobrze opisanymi i coraz lepiej poznawanymi czynnościami mózgu i ludzkiej psychiki, są także związane z ciałem jako całością. W związku z tym nauka nie widzi potrzeby wprowadzania tu dodatkowych, nieoperacyjnych i niemierzalnych pojęć ze świata nadprzyrodzonego. Wszystkie te funkcje ludzkie są wnikliwie badane i opisywane, stają się coraz bardziej uchwytne dla naukowego obrazu człowieka. Nauka nie wykracza tu poza swoje kompetencje, to raczej filozoficzne ujęcie duszy weszło na teren, który badają nauki ścisłe. Dla przykładu badania nad tzw. ucieleśnieniem (embodiment) pokazują, że pamięć, poznanie matematyczne i inne zadania umysłu nie pozostają bez związku z pozycją ciała, jego ruchem czy przestrzenią wokół niego. ${ }^{3}$ Czynności, które określamy tradycyjnie jako psychiczne czy duchowe, są silniej związane z ciałem niż się nam intuicyjnie wydaje. To sugeruje, że człowiek w swych różnych funkcjach i aspektach jest niepodzielny.

Tradycyjnie rozumiana dusza nie jest też pojęciem biblijnym. Biblia nie dzieli człowieka na ciało i duszę, jak robiła to jeszcze do niedawna filozofia, teologia i tradycja chrześcijańska. Podział taki wywodzi się z filozofii starożytnej, a początki zawdzięcza Sokratesowi, który nadał pojęciu psyche nowe znaczenie. Dusza stała się tożsamością człowieka, jego ,ja”, tym, co go odróżnia od zwierząt. ${ }^{4}$ Naukę tę rozwinął uczeń Sokratesa, Platon, i to on jest dziś kojarzony z podziałem ciało-dusza oraz powiedzeniem, że ciało jest więzieniem duszy (lub w innej wersji: człowiek to dusza uwięziona w ciele),

3 Szerzej zob. M.L. A n d e r s o n, How to Study the Mind. An Introduction to Embodied Cognition, w: F. S a n t o i a n n i, C. S a b a t a n o (red.), Brain Development in Learning Environments. Embodied and Perceptual Advancements, Cambridge Scholars Press, Cambridge 2007, s. 65-82; A. G o 1 d m a n, A Moderate Approach to Embodied Cognitive Science, Review of Philosophy and Psychology 3/2012, s. 71-88.

4 W systemie arystotelesowsko-tomistycznym zwierzęta także mają duszę substancję ożywiającą materialną strukturę ciała - ale nie taką, jaką ma człowiek, np. nie nieśmiertelną. 
a śmierć jest uwolnieniem, oddzieleniem duszy od ciała (spirytualizm). Tym tropem poszedł Arystoteles ${ }^{5}$ i późniejsza filozofia, jak np. hylemorfizm św. Tomasza. ${ }^{6}$ Człowiekiem, który przypieczętował koncepcję silnego dualizmu ciało-dusza w filozofii chrześcijańskiej był Kartezjusz, dla którego dusza to res cogitans, rzecz myśląca i poznająca (nadnaturalna, niepodlegająca prawom przyrody), a ciało to res extensa, rzecz rozciągła (podlegająca prawom przyrody). Od Kartezjusza wywodzi się przekonanie, że świadomość jest czymś różnym od ciała, konsekwencją czego ukształtował się radykalny dualizm antropologiczny. Filozof uważał, że doświadczenia umysłowe są funkcją duszy i - w związku z tym, że dusza jest niematerialna nie mogą zostać umiejscowione w żadnym określonym narządzie ciała. Jednocześnie dusza i ciało wzajemnie na siebie oddziałują, a miejscem, w którym ta interakcja zachodzi - swoistym pomostem psychofizycznym - jest szyszynka. ${ }^{7}$

Kartezjańskie wyjaśnienie odwiecznego problemu psychofizycznego człowieka (tzw. mind-body problem) wydaje się intuicyjnie słuszne, gdyż z jednej strony doświadczamy materialnego mózgu i materialnych zachowań naszego ciała, a z drugiej niematerialności naszej myśli i świadomości. Jest to jednak dualizm pozorny, który od dawna nie zadowalał wielu myślicieli. Już Kartezjusza nurtowało, jak dwie istotowo różne formy bytu - res cogitans i res extensa-mogą na siebie oddziaływać. Rozwiązań nierealistycznych dawano wiele (np., że myśl o ruszeniu nogą jest modlitwą, a efekt fizyczny jest

5 Szerzej zob. J.N. B re m m e r, The Soul in Early and Classical Greece, w: J. F i g 1, H.-D. K 1 e i n (red.), Der Begriff der Seele in der Religionswissenschaft, Königshausen \& Neumann, Würzburg 2002, s. 159-169.

6 Szerzej zob. S. S w i e ż a w s k i, Święty Tomasz na nowo odczytany, Instytut Wydawniczy Znak, Kraków 1983, s. 98-100.

7 Kartezjusz wybrał szyszynkę, gdyż mieści się ona w środku głowy; drugim powodem był ówczesny pogląd, że występuje ona jedynie u człowieka - ludzie są jedynymi istotami z racjonalnymi duszami; szyszynka jest ponadto jedyną strukturą w głównej części mózgu niedzielącą się na dwie części, wydawała się więc Kartezjuszowi jedynym narządem będącym w stanie integrować obrazy płynące $\mathrm{z}$ oczu w jedno spostrzeżenie. 
działaniem Boga, realizacją tej modlitwy), ale szybko okazało się, że ten arbitralny podział stwarza więcej problemów, niż wyjaśnia. Dzisiejsza nauka, zwłaszcza neuronauka, dogłębnie bada mind-body problem i wskazuje, że człowiek jest jeden i niepodzielny - nie jest „składakiem” z przeciwstawnych części: materialnej i niematerialnej, która nią kieruje. Za myślenie, odczuwanie, decyzje, wolę, pamięć, świadomość itd. - a więc funkcje przypisywane dotąd duszy - odpowiada nasze ciało, a w szczególności mózg, w którym łączą się czynności psychofizyczne. Naukowcy posługują się czasem pojęciem duszy, ale w znaczeniu ludzkiej psychiki bądź ludzkiego umysłu. ${ }^{8}$

Co ciekawe, Biblia i jej antropologia, jest tu bliższa dzisiejszemu naukowemu obrazowi niż koncepcje filozoficzne. Koncepcja ciałodusza wprowadza radykalny dualizm, podział człowieka na dwie istotowo różne części. Tymczasem Pismo Święte mówi, że Bóg stworzył człowieka jako integralną jedność. Człowiek nie tyle ma duszę, ile jest duszą (hebr. nefesz, np. Rdz 2,7; 12,5); człowiek nie tyle ma ciało, ile jest ciałem (hebr. basar, np. Ps 56,5; Hi 34,15). Nefesz oznacza w Biblii całego człowieka, podkreślając jedynie, że ma on w sobie życie, że jest różny od przedmiotów martwych, o czym świadczy oddychanie (np. Kpł 17,11; 2Sm 1,9). ${ }^{9}$ Nefesz nie oznacza duszy w rozumieniu

8 Pojęciem duszy posługują się także twórcy kultury, ale niekoniecznie w znaczeniu teologicznym. Dusza w systemach takich jak chrześcijaństwo może oznaczać realne istnienie człowieka po śmierci (nieśmiertelność realna), a w innych jedynie symbol szczególnej godności człowieka oraz wiecznej wartości jego działań (nieśmiertelność metaforyczna, w dziełach, w pamięci); zob. D. C o c k b u r n, Two Views of the Soul, Cogito 3/1989, s. 26-30.

9 Znaczenie hebr. nefesz jest szerokie i wieloaspektowe, poczynając od „szyja”, „,gardło”, „przełyk”, „oddech”, „dech”, „tchnienie” po „,̇ycie”, ,żywe stworzenie”, „osoba”, ,człowiek”, „,uczucia”, „,duch”, „wola”; ma też funkcję zaimka zwrotnego, wskazującego i inne. Na pierwszy plan wysuwa się tu znaczenie życia, rozumianego jako niematerialny czynnik egzystencji. Szczegółowa analiza tego pojęcia wykracza poza ramy tego artykułu. Zob. szerzej w najnowszej pracy: R.C. S t e i n e r (red.), Disembodied Souls. The Nefesh in Israel and Kindred Spirits in the Ancient Near East, with an Appendix on the Katumuwa Inscription, Society of Biblical Literature, Atlanta 2015, s. 68-81; a także A.I. B a u m g a r t e n, J. A s s m a n n, G.G. S t r o u m a (red.), Self, Soul and Body in Religious Experience, Studies 
platońsko-kartezjańskim, ale żyjącą istotę, w związku z czym także zwierzęta są „duszą żywą” (Rdz 2,19). Funkcje psychiczno-duchowe przypisywane są w Biblii częściom ciała (sercu, nerkom, głowie, wątrobie, łonu, oczom, uszom itd.) i nie są oddzielone od części somatycznej. Dusza, duch, serce wskazują duchową sferę człowieka, która jednak nie istnieje bez cielesnej. Nie ma człowieka bez ciała (basar), jak i nie ma człowieka bez pierwiastka życia (nefesz): człowiek jest uduchowionym ciałem i ucieleśnionym duchem. Biblia głosi więc monizm antropologiczny, w którym nie ma napięcia dostrzegalnego w wizji greckiej. ${ }^{10}$ Czasem termin nefesz zastępowany jest synonimicznym ruach („tchnienie”, „dech”, „wiatr”, „duch”), jak w Ps 78,39: „Przypominał sobie, że są tylko ciałem [basar] i tchnieniem [ruach], które odchodzi, a nie wraca", który wskazuje na coś równie nietrwałego, jak ciało. W biblijnym opisie człowiek nie ma „duszy” w rozumieniu samodzielnej rozumnej egzystencji poza ciałem lub w oderwaniu od ciała.

Wnioski dzisiejszej nauki są więc - paradoksalnie - nie antyreligijne, ale bliskie nauczaniu biblijnemu. Podział człowieka na „ciało” i „duszę” w starożytności i średniowieczu wynikał z tego, że próbowano go opisać $\mathrm{w}$ jego aspekcie materialnym i niematerialnym. Próbowano rozwiązać odwieczny problem psychofizyczny, zbudowano zatem „model człowieka”, dzieląc go na bezcielesną

in the History of Religions 78, Brill, Leiden 1998; J. B r e m e r, Problem umyst-ciało, WAM, Kraków 2001; J.B. W o o d w a r d, Man as Spirit, Soul, and Body. A Study of Biblical Psychology, Grace Fellowship International, Pigeon Forge 2007; J.B. Gre e n, Soul, w: K. D o o b S a k e n feld (red.), The New Interpreter's Dictionary of the Bible, t. V, Abingdon, Nashville 2009, s. 358-369; C. F r e v e 1 (red.), Biblische anthropologie. Neue einsichten aus dem Alten Testament, Herder, Freiburg-Basel-Wien 2010.

10 Dopiero pod wpływem myśli greckiej, w napisanej po grecku Księdze Mądrości i momentami u św. Pawła, widać elementy owego napięcia między duszą (psyche) a ciałem (sarx). Najsławniejszy opis tego napięcia w Rz 7,16-24 („Nie czynię bowiem dobra, którego chcę, ale czynię to zło, którego nie chcę") jest toposem zaczerpniętym z Medei Eurypidesa, jest to najbardziej znane Pawłowe zapożyczenie z literatury greckiej. Ten sam motyw pojawia się także u Owidiusza (Metamorfozy) oraz u Epiteta (Colloquia). 
formę i cielesną materię. Był to wyraz przednaukowych filozoficznych analogii w celu nazwania materialnych i niematerialnych własności człowieka. Wydaje się, że dualizm dusza-ciało może być nie tyle odbiciem rzeczywistości, ile naszym sposobem intuicyjnego jej opisu, naszej potrzeby kategoryzowania i porządkowania zjawisk, jakich doświadczamy. Tak postrzegamy rzeczywistość, która być może w swej istocie nie jest podzielona. Jest ona podzielona dla nas.

Co w takim razie z czyśćcem $\mathrm{i}$ istnieniem człowieka po śmierci do zmartwychwstania ciała na sądzie ostatecznym? Gdy prześledzimy wypowiedzi Magisterium Kościoła o duszy ludzkiej, to zobaczymy, że to pojęcie nie tyle jest potrzebne do opisu kondycji człowieka na ziemi, ale właśnie by wskazać na ciągłość relacji z Bogiem między śmiercią jednostki a powszechnym zmartwychwstaniem ciał na sądzie (np. w kwestii nauki o czyśćcu). Kongregacja Doktryny Wiary wydała w 1979 r. dokument na temat niektórych kwestii eschatologicznych, notuje tam: „Kościół stwierdza dalsze istnienie i życie - po śmierci - elementu duchowego obdarzonego świadomością i wolą w taki sposób, że «ja» ludzkie trwa nadal. Na oznaczenie tego elementu Kościół posługuje się słowem «dusza», dobrze znanym w Piśmie Świętym i w Tradycji. Chociaż wyraz ten przybiera w Biblii różne znaczenia, Kościół uważa jednak, że nie ma ku temu żadnej poważnej racji, aby go odrzucić, owszem, uznaje za rzecz bezwzględnie konieczną mieć jakiś ś r o d e k sło w n y [podkreślenie moje] dla uzasadnienia wiary chrześcijańskiej". Tekst ten co prawda argumentuje za pozostaniem przy pojęciu „duszy”, jednak przyznaje, że ma ono różne znaczenia i stosowane jest jako językowa forma, środek słowny nazwania trwania ludzkiego ,ja” po śmierci. A zatem, że w razie lepszego „środka słownego" mogłoby być zmienione.

Na temat życia po śmierci Pismo Święte wypowiada się skromnie, by nie powiedzieć, że niemal milczy, unikając precyzowania tego tematu i uciekając się do nielicznych metafor i form poetyckich, jak obraz Szeolu, łona Abrahama czy retorycznego ,ani oko nie widziało...". Brak jakiegokolwiek systematycznego opisu 
rzeczywistości ostatecznych. ${ }^{11}$ Wydaje się więc, że także my powinniśmy w tej materii wypowiadać się ostrożnie, ze świadomością, iż prawdy wiary, szczególnie te dotyczące życia po śmierci, mogą być tłumaczone za pomocą różnych modeli. W chrześcijaństwie spotykamy np. koncepcję, że śmierć jest czasowym zawieszeniem istnienia aż do wskrzeszenia na sądzie ostatecznym, że dusza jest tzw. complex information-bearing pattern (J. Polkinghorne), a także inne modele. Problem rozumienia duszy i jej stanu po śmierci jest problemem bardzo złożonym i napotykającym trudności sprawiające czasem wrażenie niemożliwych do rozwiązania. Szeroko problem ten opisuje filozof Ireneusz Ziemiński. ${ }^{12}$ Dusza żyjąca po śmierci może być czymś radykalnie innym niż do tej pory sobie wyobrażaliśmy. Czy jesteśmy uprawnieni do budowania nowych modeli? Jak pokazałem, Biblia przychodzi tu z pomocą; warto też zaznaczyć, że chrześcijaństwo nie wyznaje „wiary w duszę”: ani w Credo, ani w symbolu wiary nie ma o niej mowy. Jest wiara w zmartwychwstanie ciała, w to, że ja, jako osoba, zmartwychwstanę. Na II Soborze Watykańskim i po nim widać odejście od pojęcia „dusza” na rzecz pojęcia „osoba”, co wydaje się związane z powrotem do antropologii biblijnej i integralnego spojrzenia na człowieka. Wydaje się to zachętą do poszukiwania nowych sposobów wyrażenia nadprzyrodzonego powołania człowieka, takich, które nie wchodzą na teren empiryczny.

\section{Grzech pierworodny i jego interpretacja w kontekście ewolucji}

To, że teorię ewolucji wszechświata i przyrody należy pogodzić z biblijnym obrazem stworzenia, jest dziś dla ludzi wierzących coraz

11 Szerzej zob. T. N i e m a s, Perspektywa eschatologiczna proegzystencji wierzacych w przekazie Pisma Świętego, TUM Wydawnictwo Wrocławskiej Księgarni Archidiecezjalnej, Wrocław 2016.

12 I. Z i e m i ń s k i, Życie wieczne. Przyczynek do eschatologii filozoficznej, W drodze, Poznań-Kraków 2013, s. 37-45. Do podobnie sceptycznych wniosków doszedł jezuicki teolog Karl Rahner, który pojęcie tzw. stanu pośredniego i trwania „duszy oddzielonej” (anima separata) uznał za „nieszkodliwą mitologię”. 
bardziej oczywiste. ${ }^{13}$ Ksiądz Michał Heller poczynił wiele na tym polu, aby wskazać, że ewolucja i stworzenie nie wykluczają się, ale są to dwa różne obrazy i dwa różne języki - naukowy i religijno-poetycki - opisu jednej rzeczywistości. Problem polega na tym, że wiele konkordystycznych (uzgadniających) rozwiązań upraszcza albo wiedzę biologiczną, albo teologiczną, przed czym ks. Heller słusznie przestrzega. Pojawiają się próby wykorzystania Biblii w niewłaściwy sposób, doszukujące się treści, o których ona nie mówi. Dla przykładu zdania: „Niechaj ziemia wyda rośliny zielone” (Rdz 1,11) i „Niechaj ziemia wyda istoty żywe różnego rodzaju" $(\mathrm{Rdz} 1,24)$ interpretuje się jako dowód na ewolucję życia.

Nawet jeśli uniknie się płytkich konkordyzmów, pozostaje ważne zagadnienie, które ciągle czeka na teologiczne rozwinięcia i nowe modele w ramach ewolucyjnego obrazu świata i człowieka, a ostatecznie na głos Magisterium Kościoła w tej sprawie. Chodzi o grzech pierworodny. Pytanie stawiane od czasów Karola Darwina, ale chyba ciągle bez satysfakcjonującej odpowiedzi, brzmi: Jak pogodzić biblijną naukę o grzechu pierworodnym $\mathrm{z}$ teorią ewolucji? Jak ją uzgodnić z faktami, które świadczą, że historia człowieka kształtowała się inaczej, niż przedstawia to Księga Rodzaju?

Pierwsze rozdziały Księgi Rodzaju opowiadają o tym, że Bóg stworzył parę prarodziców i umieścił ją w raju, gdzie cieszyli się nieśmiertelnością, bezgrzesznością i doskonałością, a potem, w wyniku grzechu pierworodnego, sprowadzili na siebie i całą ludzkość skażenie natury i śmierć. Człowiek po grzechu pierworodnym stał się samolubny i pyszny, a na świat przyszły cierpienie i umieranie. Tak zdaje się rozumieć te teksty autor Księgi Mądrości, a naukę o winie Adama i jej konsekwencjach rozwija św. Paweł w Liście do Rzymian w kontekście odkupieńczego dzieła Chrystusa, drugiego Adama. Kolejnymi filarami doktryny o grzechu pierworodnym stały

13 Poza zwolennikami tzw. Inteligentnego Projektu oraz kreacjonistami, rzecznikami dosłownej interpretacji Księgi Rodzaju. 
się nauczanie św. Augustyna ${ }^{14}$ i lokalnych synodów jego czasów, a ostatecznie Sobór Trydencki, który w dekrecie O Grzechu Pierworodnym uczynił z niej dogmat wiary.

W świetle dzisiejszej wiedzy o powstaniu człowieka (antropogenezy), źródłach jego moralności i stanie jego natury dawna wykładnia $\mathrm{i}$ interpretacja tego dogmatu wydaje się nie do utrzymania. W tradycyjnym rozumieniu $\mathrm{Rdz} 2-3$ był w historii czas (raj), w którym człowiek doświadczał innego rodzaju egzystencji, w którym żył na ziemi w stanie po wieloma względami zaprzeczającym naturze przyrody i naturze człowieczeństwa. Bowiem do natury człowieczeństwa należy niedoskonałość, skłonność do zła moralnego, choroba, trud i cierpienie, płciowość naznaczona pożądaniem, rywalizacja między gatunkami i wewnątrzgatunkowa, a wreszcie śmierć. Nauki o historii ziemi i antropogenezie (paleoantropologia, biologia ewolucyjna itd.) dowodzą, że tak było od początku istnienia żywych istot i człowieka na ziemi, nie zostawiają zatem żadnego miejsca na cudowny, rajski okres dziejów praludzkości wywodzącej się od jednej pary. Śmierć, wrogość i wzajemne zabijanie się różnych gatunków, wymieranie, choroby, pożądliwość, dysfunkcje, mutacje i wszelkiego rodzaju zło fizyczne i moralne - istniały w świecie od samego początku istnienia życia, a kataklizmy i katastrofy od początku istnienia kosmosu. Nie są więc efektem historycznego grzechu, ale są wpisane w naturę funkcjonowania świata. W naukowym obrazie rzeczywistości nie ma miejsca na biblijny raj i jego doskonałości.

Czy wobec tego dogmat o grzechu pierworodnym da się pogodzić z naukowym obrazem świata? Popularne jest ujęcie grzechu pierworodnego jako przyczyny aktualnego stanu człowieka: ludzkiej skłonności do zła, osłabienia zdolności jasnego poznania prawdy oraz słabości woli, która doznaje rozbicia między pragnieniem dobra a tendencją ku złu moralnemu. Jednak te aspekty człowieczeństwa wyjaśnia z dużym sukcesem biologia ewolucyjna (takie wielkie zagadnienia jak neurony lustrzane, empatia, protomoralność, egoizm, emocje

14 Zob. św. A u g u s t y n, O państwie Bożym. Przeciw poganom ksiag XXII, tłum. W. K or n a t o w s k i, Instytut Wydawniczy Pax, Warszawa 1977. 
moralne, altruizm krewniaczy i altruizm odwzajemniony, współpraca i rywalizacja, dobór płciowy i konkurencja wewnątrz- i międzygatunkowa itp.). To, co tradycyjnie przypisuje się dramatycznemu wydarzeniu z praprzeszłości, wydarzeniu Wielkiego Upadku, okazało się czymś ewolucyjnie wynikającym z antropogenezy. Innymi słowy struktura „stanu upadku”, „stanu skażenia natury ludzkiej” nie jest historycznym przygodnym położeniem człowieka, ale stałą antropologiczną. Jeśli rację mają nauki przyrodnicze, nie było w historii okresu, w którym człowiek doświadczyłby harmonii takiej, jak zobrazowano to w Księdze Rodzaju. W tym kontekście wydaje się, że natura człowieka i świata nie wymaga wyjaśnień w kategoriach pierwotnej doskonałości i upadku. Słabość, grzeszność, cierpienie i śmierć są częścią natury, a skłonność człowieka do zła nie jest czymś zawinionym, lecz jest jego wyposażeniem ewolucyjnym, za które nie ponosi odpowiedzialności. ${ }^{15}$

Fakty te rodzą zasadnicze pytania: Czym właściwie jest grzech pierworodny, jeśli skłonność do zła moralnego jest dziedzictwem ewolucji? Jak jest on przekazywany, jeśli potwierdzi się, że ludzkość nie pochodzi od jednej pary prarodziców, ale od wielu par (poligenizm)? Jak rozumieć naukę o biologicznym dziedziczeniu grzechu pierworodnego, jeśli potwierdzi się stanowisko o wielu gatunkach ludzkich, z których wyłonił się człowiek współczesny (polifiletyzm)? Opór teologów budzi pomieszanie dwóch różnych porządków: biologicznego i teologicznego, gdzie porządek biologiczny (dziedziczenia) wchodzi na obszar wolności (grzech) - na co zwracał już uwagę Paul Ricouer. ${ }^{16}$

15 Szerzej zob. R. A le x a n d e r, The Biology of Moral Systems, Aldine de Gruyter, New York 1987; J. R a c h e l s, Created From Animals. The Moral Implications of Darwinism, Oxford University Press, Oxford 1990; G. B o n i o l o, G. D e A n n a, Evolutionary Ethics and Contemporary Biology, Cambridge University Press, Cambridge 2006; R. J o y c e, The Evolution of Morality, Massachusetts Institute of Technology Press, Cambridge 2006.

16 Pisał on: „Spekulacja nt. dalszego przekazywania grzechu, pochodzącego od pierwszego człowieka, jest późną racjonalizacją, w której mieszają się kategorie etyczne i biologiczne"; zob. Paul R i c o u e r, Symbolik des Bosen. Phänomenologie der Schuld II, tłum. M. O t t o, Karl Alber, Freiburg-München 1971, s. 99. 
Jak pogodzić jednostkową winę grzechu pierworodnego $\mathrm{z}$ jego powszechnością? Czyli dlaczego grzech jednego człowieka dziedziczą wszyscy? W jaki sposób poczynił on nieodwracalne skutki w historii i naturze ludzkiej? Czy jest możliwe, by pojedynczy grzech miał moc zmiany natury i determinowania dziejów ludzkich do tego stopnia, że wszyscy będą potrzebowali zbawienia? Czy grzech pierworodny to strata czy zyskanie czegoś? Czy wymusza on wiarę w inny, idealny stan naszej natury wbrew danym naukowym? Kolejna aporia (trudność, sprzeczność) pojawia się na płaszczyźnie pojęcia grzechu: Jak rozumieć dziedziczność grzechu, skoro do jego istoty i definicji należy element osobistej odpowiedzialności i wolnej woli człowieka? Wyjaśnienia wreszcie domaga się obraz biblijny, ponieważ jeśli raj rozumiemy jako posiadanie wszystkiego w pełni, to gdzie w takim porządku znajduje się miejsce na niezadowolenie i pożądanie prarodziców, bez którego grzeszne zachowanie nie byłoby możliwe?

To tylko niektóre pytania stawiane dogmatowi. Sprawiły one, że druga połowa XX w. przyniosła największe od czasów św. Augustyna - teoretyka grzechu pierworodnego - zmiany w rozumieniu tej teologicznej konstrukcji. W tym temacie większe zmiany nastąpiły w ciągu ostatnich 50 lat niż w ciągu 15 wieków. Tradycyjne rozumienie grzechu pierworodnego zostało zrewidowane, temat uległ pogłębieniom i modyfikacjom prowadzącym czasem do negacji całego dogmatu (w pracach takich badaczy, jak np. H. Junker, L. Robberechts, H. Haag, S. Duffy, J. Gross, H. Küng, U. Baumann, J. Vermeylen, E. Drewermann) ${ }^{17}$ Nowe, rozszerzające i modyfikujące, interpretacje wyszły od takich teologów, jak np. H. Rondet, A. Vannest, P. Schoonenberg, P. Teilhard de Chardin, S. Lyonnet, A. Hulsbosch, M. Hurley i inni. Wielu teologów katolickich (np. P. Schoonenberg, H. de Lubac, M. Hurlej i inni) traktuje grzech pierworodny strukturalnie i utożsamia go z grzechem świata

17 Np. S.J. D u ffy pisał: „Actually there is no doctrine of original sin in Scripture"; t e n ż e, Our Hearts of Darkness: Original Sin Revisited, Theological Studies 49/1988, s. 598. 
lub grzesznością strukturalną bytu ludzkiego, jak czyniło to wielu Ojców wschodnich, np. Teodoret z $\mathrm{Cyru}^{18}$ - a więc zupełnie inaczej niż tradycyjna wykładnia. Te daleko idące zmiany i rozwinięcia nie wyraziły się jeszcze nowym stanowiskiem Kościoła w tej sprawie. Katechizm Kościoła Katolickiego utrzymuje historyczność i dosłowność jednostkowego wydarzenia grzechu popełnionego w raju (KKK nr 390): „Opis upadku (Rdz 3) używa języka obrazowego, ale stwierdza wydarzenie pierwotne, fakt, który miał miejsce na początku historii człowieka (por. Sobór Watykański II, konst. Gaudium et spes, 13). Objawienie daje nam pewność wiary, że cała historia ludzka jest naznaczona pierworodną winą, w sposób wolny zaciągniętą przez naszych pierwszych rodziców".

Mimo pewności, z jaką wypowiada się KKK, współczesna teologia biblijna i teologia $\mathrm{w}$ ogóle są znacznie bardziej powściągliwe, unikają tematu grzechu pierworodnego ${ }^{19}$ albo przeinterpretowują teksty św. Pawła (Rz 5), Psalmu 51: „Oto zrodzony jestem w przewinieniu i w grzechu poczęła mnie matka" (w. 7) i inne bazujące na Rdz 2-3. Egzegeza biblijna stoi na stanowisku, że aby odczytać znaczenie teologiczne tekstu o upadku prarodziców, należy właściwie ująć gatunek prehistorii biblijnej (Rdz 1-11). Z tej perspektywy opowiadania z Rdz 1-11 należy traktować nie jako historię, ale tekst mądrościowy i mit religiotwórczy. Jeśli mówię o micie, to nie w znaczeniu pozytywistycznym (bajka, wymysł), ale w znaczeniu, jakie nadaje temu gatunkowi teoria literatury: mit to starożytne podejście poznawcze do rzeczywistości, próba docierania, czasem intuicyjnego, do istotnych ludzkich prawd. Był to dla prastarych cywilizacji jedyny znany sposób opowiadania o początkach świata i człowieka. Mit był echem ważnych mądrościowych intuicji i stanowił filozofię pierwotnego człowieka. Biblia w długim procesie powstawania przypada na okres

18 Zob. Cz.S. B a r t n i k, Dogmatyka katolicka, t. I, Wydawnictwo KUL, Lublin 2012, s. 342-360.

19 Np. najnowsze obszerne opracowanie: A. N a p i ó r k ow s k i, Teologie $X X$ i XXI wieku, Wydawnictwo WAM, Kraków 2016, s. 450 nie notuje ani jednego punktu czy autora zajmującego się tym tematem. 
powszechnego panowania poznania mitycznego, który trwał jeszcze po pojawieniu się myślenia filozoficznego (proto-naukowego) i historiografii starożytnej w V w. przed Chr. na terenie Grecji. Tak więc nie może dziwić obecność tego sposobu wypowiadania się w Biblii. Opowiadania z Rdz 1-11 należą do tzw. prehistorii biblijnej, zatem opowiadają o czymś, co było przed historią lub poza historią i czynią to nie na sposób historyczny, ale wyobrażeniowy i mądrościowo-dydaktyczny. Tekst ten wykazuje pewne zapożyczenia z mitycznej literatury bliskowschodniej. Największy wpływ na początkowe rozdziały Księgi Rodzaju miały akadyjski epos o Gilgameszu oraz babiloński poemat Enuma Elisz, rozpowszechnione na starożytnym Wschodzie, na co wskazują ich liczne starożytne kopie, odpisy i świadectwa. W kontekście grzechu ważny jest zwłaszcza ten drugi epos, który wyraża wspólny z biblijnym pogląd, że wszechświat został stworzony przez osobowe bóstwo, a człowiek zajmuje w nim szczególne miejsce, żyjąc w uprzywilejowanej relacji z boskością. Podobnie jak w Biblii, w Enuma Elisz człowiek nie jest zdolny zachować się odpowiednio do wyznaczonych mu ideałów, co sprowadza na niego nieszczęście i śmierć. Powyższe dane egzegetyczne implikują złożone zagadnienie: co z biblijnego mitycznego i symbolicznego obrazu stworzenia i raju należy do zmiennej formy, a co do niezmiennej istoty nauczania biblijnego. Jak oddzielić to, co paradygmatyczne dla teologii, od tego, co jest historycznie uwarunkowane? ${ }^{20}$

Studia nad specyfiką pisarską autora Rdz 2-3 (tzw. tradycji jahwistycznej z VII/VI w. przed Chr.; inni: z X w. ${ }^{21}$ ), sugerują, by Rdz 3 traktować jako etiologię (ludowe wyjaśnienie) skłonności natury

${ }^{20}$ Papieska Kom isja Biblijna, Biblia a moralność Biblijne korzenie postępowania chrześcijańskiego, tłum. R. R u bi n ki e w i c z, Verbum, Kielce 2009 w nr. 106 wskazuje w tekstach z Księgi Rodzaju 1-3 „dwa biblijne elementy, których brak w mitach mezopotamskich. Chodzi o Bożą troskę o ludzkość i ludzką odpowiedzialność za kontynuowanie stworzenia”. Inne elementy - jak interesujące z naszego punktu widzenia grzech, zło i śmierć - traktuje jako porcje „mądrości naturalnej”, wspólnej z niektórymi systemami religijnymi czy filozoficznymi.

${ }^{21}$ Szerzej zob. T.B. D o z e m a n, K. S c h m id (red.), Farewell to the Yahwist? Society of Biblical Literature, Atlanta 2006. 
ludzkiej do zła i próbę odpowiedzi na odwieczne pytanie stawiane przez człowieka: Unde malum? Skąd zło? Dlaczego człowiek jest tak wewnętrznie i zewnętrznie skonfliktowany? Po tej linii szły niektóre starożytne interpretacje. Pelagiusz np. uważał Adama za pierwszego sprawcę grzechu, jednak odrzucał prawdę o możliwości jego dziedziczenia. ${ }^{22}$ Podobnie stanowisko reprezentuje judaizm oraz protestantyzm. Także chrześcijaństwo wschodnie postrzega grzech pierworodny raczej jako stan grzechowy (katastasis hamartias), rozdarcie egzystencji między skażeniem a nieskażeniem, „grzech świata". Tu grzech pierworodny postrzega się jako naukę o złu, o śmiertelnym grzechu osobowym i o wiecznym dramacie walki między dobrem a złem w człowieku jako jednostce i społeczności. ${ }^{23}$

Teologowie katoliccy starają się jednak zachować dogmat, wydobywając z niego różne treści i dokonując jego przemodelowania. Istnieje kilka nowych koncepcji teologicznych i nowych modeli grzechu pierworodnego, które, zachowując ramy dogmatu, wbudowują go w aktualny obraz świata, jaki dostarczają nauki. Pierwotnie zamierzałem omówić w tym artykule najważniejsze $\mathrm{z}$ tych ujęć, być może będzie to materiał na osobny tekst. Tu ograniczę się do wymienienia ciekawszych moim zdaniem modeli: grzech pierworodny jako teologiczne ujęcie momentu hominizacji, uczłowieczenia (najbardziej znany jej przedstawiciel to Pierre Telihard de Chardin); teoria mimetyczno-ofiarnicza (wypracowana przez francuskiego antropologa René Girarda, a rozwinięta w kontekście grzechu pierworodnego przez szwajcarskiego teologa Raymunda

22 Teolodzy współcześni dostrzegli potrzebę reinterpretacji nauczania Pelagiusza z wykorzystaniem jego ocalałych dzieł. Stwierdzili, że w próbach obrony wiary Kościoła zbyt negatywnie potraktowano jego doktrynę, która w rzeczywistości była mniej błędna niż sam pelagianizm; zob. szerzej A. B a r o n, Spór o Pawła, spór o człowieka czy spór o Boga? Refleksje na marginesie kontrowersji pelagiańskiej, w: t e n ż e, Pelagiusz: Komentarz do Listuśw. Pawła do Rzymian, WAM, Kraków 1999, s. 5-167; K. O b r y c k i, Koncepcja grzechu pierworodnego u Pelagiusza na podstawie jego komentarza do Listu św. Pawła do Rzymian 5,12-21, w: H. P i e t r a s (red.), Grzech Pierworodny, WAM, Kraków 1999, s. 177-185.

23 Cz. S. B a r t n i k, Dogmatyka katolicka, s. 342. 
Schwagera); możliwość alternatywnego rozwoju ludzkości (hipoteza abp. Józefa Życińskiego); interpretacja łącząca grzech pierworodny z naukową hipotezą mitochondrialnej Ewy; grzech pierworodny jako moment, w którym człowiek stał się bezwzględny w egzekwowaniu swych praw; grzech pierworodny jako rzeź bratniego gatunku (kromaniończyk wobec neandertalczyka); grzech pierworodny jako grzech zaniechania, odmowa uczynienia kroku, który w pewnym momencie należało uczynić i który został umożliwiony przez Boże wezwanie (Robert Spaemann). Wszystkie one pokazują, że choć tradycyjna doktryna o upadku pierwszych rodziców ulega w toku badań egzegetycznych, odkryć naukowych i rozwinięć teologicznych koniecznej reinterpretacji, to idea grzechu pierworodnego jest jakoś nieunikniona, jest elementem ludzkiej natury i samego procesu ewolucyjnego, zła obecnego w strukturze świata. Geny, natura i kultura sprawiają, że żyjemy w stanie oderwania od Boga. Jako istoty egoistyczne, pogubione i słabe z natury, potrzebujemy odkupienia i zbawienia w Jezusie Chrystusie. Ten wątek jest bardzo istotny, gdyż w podejściu teologicznym do tematu grzechu pierworodnego trzeba pamiętać o połączeniu tej nauki z sercem przepowiadania chrześcijańskiego, jakim jest soteriologia i głoszenie zbawienia w Jezusie. Świętemu Pawłowi doktryna o winie prarodziców, która przeszła na wszystkich, służy właśnie do wyjaśnienia przebłagania i odkupienia dokonanego w Chrystusie, wyzwolenia spod panowania grzechu, które objęło wszystkich. Grzech pierworodny to wyrażenie prawdy o potrzebie zbawienia, o tym, że ,nie ma sprawiedliwego, ani jednego" (Rz 3,10), o konieczności otwarcia ludzkiej egzystencji na dar Boga, który zbawia. Oprócz perspektywy chrystologicznej, dogmat podkreśla ważną optykę antropologiczną jedności i solidarności całej wspólnoty ludzkiej.

\section{Czy śmierć fizyczna jest skutkiem grzechu?}

Z problemem grzechu pierworodnego wiąże się zagadnienie genezy śmierci. Tu także na styku teologii biblijnej i nauki pojawia się pewne napięcie. Księga Rodzaju jako główny skutek rajskiego 
grzechu wskazuje śmierć: ,...z drzewa poznania dobra i zła nie wolno ci jeść, bo gdy z niego spożyjesz, niechybnie umrzesz” (Rdz 2,17); „Bóg powiedział: Nie wolno wam jeść z niego, a nawet go dotykać, abyście nie pomarli” (Rdz 3,4). Na tej podstawie autor Księgi Mądrości może stwierdzić: „Śmierć weszła na świat przez zawiść diabła” (Mdr 2,24), jest to wniosek z lektury rajskiego kuszenia. Dopóki jednak będzie się nauczać, że w tekście z Księgi Rodzaju i Księgi Mądrości (i podobnym u św. Pawła) chodzi o śmierć fizyczną, dopóty Biblia będzie stawiana w konflikcie z nauką. Jasne jest bowiem, że śmierć fizyczna istniała zawsze odkąd zaistniało życie, a nie dopiero od momentu prehistorycznego upadku. Należy ona do natury życia i jako taka nie jest skutkiem grzechu, towarzyszyła powstaniu i ewolucji życia na długo zanim pojawił się człowiek, a jemu towarzyszy od zawsze. Wydaje się, że wymiana pokoleń jest punktu widzenia biologii procesem korzystnym, daje bowiem miejsce kolejnym osobnikom i umożliwia zmiany dostosowawcze.

Jeśli księgi biblijne wiązałyby śmierć fizyczną z historycznym upadkiem człowieka, wówczas należałoby przyjąć, że jest to wyraz przednaukowej refleksji nad losem człowieka. Wydaje się jednak, że autorzy Księgi Rodzaju i Księgi Mądrości niekoniecznie mają na myśli powszechne zjawisko śmierci fizycznej rozumianej biologicznie, ale śmierć dotykającą jedynie człowieka, śmierć ostateczną, ontologicznie złą, rozumianą jako oddzielenie od Boga. W powszechnym odbiorze funkcjonuje błędne przekonanie o pierwotnej nieśmiertelności w raju wszelkiego życia. Biblia, mówiąc o „drzewie życia” w środku ogrodu ( $R d z 2,9)$, wskazuje na coś dokładnie przeciwnego: dopiero dostęp do tego drzewa zapewniał prarodzicom względną nieśmiertelność; przedłużanie życia było możliwe dzięki spożywaniu jego owoców. $Z$ samej natury byli więc śmiertelni. Wygnanie $\mathrm{z}$ raju było metodą oddzielenia ich od drzewa życia i ujawniło z całą mocą naturalną śmiertelność człowieka: „Prochem jesteś i w proch się obrócisz" (Rdz 3,19). O śmiertelności w raju świadczy również fakt, że Bóg uczynił pierwszej parze odzienie ze skór zwierzęcych ( $\operatorname{Rdz} 3,21)$, musiały więc być to zwierzęta martwe. W raju istniała śmierć fizyczna! Podobny wniosek umożliwia Księga Mądrości. 
Kiedy jej autor stwierdza na podstawie Rdz 3, że „śmierć weszła na świat przez zawiść diabła" (Mdr 2,24a), to zdaje się nie mieć na myśli śmierci fizycznej, dotykającej rośliny, zwierzęta i ludzi, gdyż dodaje zaraz, że „doświadczają jej ci, którzy do niego należą” (Mdr 2,24b). Skoro tylko niektórzy doświadczają śmierci (ci, należący do diabła), to nie ma tu mowy o śmierci naturalnej, procesie biologicznym dotykającym tego, co żyje. Myśl tę potwierdza zdanie: „Bo śmierci Bóg nie uczynił i nie cieszy się ze zguby żyjących" (Mdr 1,13), gdzie śmierć postawiona jest w paralelizmie synonimicznym do zguby wiecznej. Autor Księgi Mądrości skupia się na temacie eschatologii, nieśmiertelności i życia po śmierci, ten tekst należałoby zatem wpisać w szerszy kontekst tematyki eschatologicznej ostatniej księgi Pierwszego Testamentu, a nie w rozważanie o naturze życia.

Trudniejsze są teksty św. Pawła, które stanowią refleksję nad obrazami z Księgi Rodzaju i Księgi Mądrości. Apostoł Narodów pisał: „Albowiem zapłatą za grzech jest śmierć” (Rz 6,23) oraz: „Jak przez jednego człowieka grzech wszedł na świat, a przez grzech śmierć, i w ten sposób śmierć przeszła na wszystkich ludzi, ponieważ wszyscy zgrzeszyli” (Rz 5,12; zob. też całość Rz 5,12-21). Paweł wydaje się mieć tu na myśli śmierć fizyczną. Jednak możliwa jest reinterpretacja wypowiedzi apostoła w duchu Księgi Mądrości: śmierć jako religijna konsekwencja grzechu, a nie fizyczna konsekwencja życia. Zdanie z Rz 6,23 jest podsumowaniem rozdziału szóstego, czyli długiego wywodu św. Pawła na temat drogi do nowego życia w Chrystusie. ${ }^{24}$ Drogą tą jest chrzest zanurzający w śmierci Jezusa, ${ }^{25}$ przez który chrześcijanin umiera dla grzechu, przechodzi ze śmierci do życia, z niewoli do wolności, z życia dla grzechu do życia w komunii z Bogiem. Jeśli przeciwieństwem śmierci u Pawła jest nowe życie w Chrystusie i jeśli doświadcza się jej w chrzcie świętym, to nabiera

24 Szerzej zob. W. M is z t a 1, Chrzcielny charakter życia chrześcijańskiego wg $R z$ 6,1-11, Kieleckie Studia Teologiczne 3/2004, s. 401-413.

${ }_{25}$ Co do rozumienia Rz 6 jako odnoszącego się do chrztu chrześcijańskiego por. np. X. L é o n - D u fo u r, Epître aux Romains. Réédition avec des modifications, Faculté de Théologie de Fourvière, Lyon 1970, s. 73. 
ona charakteru teologicznego i sakramentalnego, a nie biologicznego. Traktując wypowiedzi św. Pawła w kategoriach biologicznych, trzeba by wysnuć nieakceptowalny wniosek, że także zwierzęta, rośliny i inne organizmy żywe zgrzeszyły lub że ponoszą konsekwencje grzechów ludzkich - bo umierają. Czy jest to zapłata za ich grzech? Umieranie jest dopiero wtedy złem, gdy jest naznaczone grzechem i odejściem od Boga. Fizyczna śmierć w wierze jest bolesna, ale nie jest złem samym w sobie, tak jak śmierć w grzechu i oddzieleniu od wspólnoty z Chrystusem. Dopiero grzech sprawia, że śmierć staje się śmiercią przeklętą. ${ }^{26} \mathrm{~W}$ takiej interpretacji śmierć bez grzechu nie byłaby egzystencjalną i duchową śmiertelnością. Umieranie staje się naprawdę dramatyczne dopiero w wyniku tego, że jego oparciem nie jest już wiara w to, że umiera się w Bogu i w drodze ku Niemu.

Katechizm Kościoła Katolickiego literalnie traktuje opowiadanie z Księgi Rodzaju o Adamie i Ewie oraz teksty św. Pawła. W związku z tym znajdują się w nim m.in. takie stwierdzenia: „Za św. Pawłem Kościół zawsze nauczał, że ogromna niedola, która przytłacza ludzi, oraz ich skłonność do zła i podleganie śmierci nie są zrozumiałe bez ich związku z grzechem Adama i faktem, że on przekazał nam grzech" (nr 403). Otóż zarówno skłonność człowieka do zła, jak i podleganie śmierci są dziś zrozumiałe z perspektywy biologii ewolucyjnej i nie potrzebują odniesienia do „grzechu Adama” rozumianego literalnie. Te i inne sformułowania Katechizmu potrzebują nowego języka i nowego naświetlenia, jeśli teologia chce być dziś wiarygodna. ${ }^{27}$

26 Szerzej zob. M. M a j e w s k i, Nieczystość śmierci $w$ Torze. Śmierć jako arcytabu, w: A. K u c z, P. M a t u s i a k (red.), Śmierć w antycznej kulturze śródziemnomorskiej, Wydawnictwo Uniwersytetu Śląskiego, Katowice 2015, s. 31-63.

27 Podobnie jest z katechizmową definicja grzechu śmiertelnego, który musi być popełniony z p ełn ą świadomością i c ałk o w it ą zgodą (zob. KKK 1857). Taka definicja okazuje się w świetle dzisiejszej wiedzy neuropsychologicznej co najmniej nieprecyzyjna. Nauki empiryczne o człowieku (psychologia, biologia, neuronauki) dryfują w kierunku determinizmu - wykazania, że wszystkie zachowania człowieka są warunkowe, czymś zdeterminowane i w pewnej mierze automatyczne. Odbywa się w nas ogrom procesów nieświadomych i uwarunkowanych genetycznie, 


\section{Czy możemy poznać Boga z Jego dziel?}

Autor Księgi Mądrości pisze: „Głupi z natury są wszyscy ludzie, którzy nie poznali Boga (...) patrząc na dzieła, nie poznali Stwórcy” (Mdr 13,1). I dodaje: „Bo z wielkości i piękna stworzeń poznaje się przez podobieństwo ich Stwórcę" (Mdr 13,5). Tego samego argumentu z natury, ze stworzenia, używa św. Paweł: „Albowiem od stworzenia świata niewidzialne Jego przymioty - wiekuista Jego potęga oraz bóstwo - stają się widzialne dla umysłu przez jego dzieła, tak że nie mogą się wymówić od win" (Rz 1,20). Są to często cytowane teksty o tym, że Boga można poznać nie tylko z Księgi Objawienia (Biblii), ale także z Księgi Natury (przyrody), z Jego dzieł. W argumentowaniu za istnieniem, dobrocią i wielkością Boga sugerują wspieranie się konstatacjami z obserwacji stworzonego świata.

Tu pojawia się trudność podnoszona nierzadko przez naukowców. Mianowicie, z jednej strony piękno jezior i oceanów, majestat gór, bogactwo przyrody i ogrom kosmosu rzeczywiście skłaniają do kontemplacji stworzenia i dopatrywania się w nim śladów Stwórcy, wielkiego, dobrego i mądrego Boga. Ale z drugiej strony natura to także mutacje i mutanty genetyczne, dysfunkcje w organizmach,

somatycznie, socjologicznie, tak że wiele z czynności, które uważamy za wolne, są tak czy inaczej zdeterminowane (tzw. iluzja wolnej woli). Dlatego mówienie o pełnej świadomości i całkowitej dobrowolności, jako warunku grzechu ciężkiego, wymaga doprecyzowania. Znaczna część naszych przekonań o sprawstwie, naszej w pełni świadomej decyzyjności to złudzenia (np. uleganie reklamie podprogowej). Jest bardzo wiele eksperymentów psychologicznych, które dowodzą, że decyzje jakie uważamy za swoje i podjęte w sposób w pełni wolny - są wcześniej czymś zdeterminowane (np. zjawiskiem primingu), czego zupełnie nie jesteśmy świadomi. Działamy w pewnej mierze automatycznie, poruszani mechanizmami wrodzonym, odziedziczonymi czy nabytymi. Człowiek nie wie, że coś na niego wpływa, że podlega wpływowi, wydaje mu się że to on zawsze i we wszystkim jest podmiotem decyzji. Dlatego katechizmowa definicja mówiąca o stuprocentowej wolnej woli i stuprocentowej świadomości niezbędnej do popełnienia grzechu ciężkiego wydaje się tracić znaczenie, gdyż takiej świadomości i wolności nigdy nie uzyskamy. $\mathrm{Z}$ aktualnej definicji grzechu śmiertelnego wynika, że żaden człowiek nigdy nie popełnił takiego grzechu. 
deformacje, niedorozwój fizyczny i umysłowy, choroby i śmierć, odwieczna agresja stworzeń, niedostosowanie i w konsekwencji wymieranie olbrzymiej liczby gatunków roślin i zwierząt (szacuje się, że w dotychczasowej historii naszej planety 99,9\% gatunków zwierząt, jakie żyły na ziemi, wyginęły przez brak dostosowania. Proces wymierania gatunków jest niemal tak samo powszechny jak proces ich powstawania). Jak przypisać Bogu takie sytuacje w przyrodzie, jak skrzyżowanie układu oddechowego z pokarmowym u ssaków prowadzące do zakrztuszeń i śmierci, światłoplamka na siatkówce oka, wyrostek robaczkowy, zęby mądrości, skłonność do hemoroidów i inne niedoróbki i pozostałości ewolucyjne? ${ }^{28} \mathrm{Co}$ poznajemy o Stwórcy z takich stworzeń jak obojnaki wśród ludzi (osoby, które wbrew biblijnemu „stworzył ich mężczyzną i kobietą” rodzą się bez określonej płci, np. z narządami częściowo męskimi i żeńskimi, hermafrodyci), jak osoby o nietypowej orientacji seksualnej czy mające wrodzone parafilie (zboczenia seksualne), jak dzieci syjamskie czy pasożyty, które składają jaja w ciele gospodarza, by wyklute larwy powoli zjadały go żywcem od środka? Co o projekcie natury mówią nam zwierzęta pożerające swego partnera czy własne potomstwo (sytuacje nie tak rzadkie w przyrodzie)?

Biologia i nauki ewolucyjne uczą, że natura działa ślepo, przypadkowo i niedoskonale, często jest okrutna. Dobór naturalny jest kumulatywny, krótkowzroczny i zadowala się pseudorozwiązaniami (tzw. oportunizm), postępuje nie jak doskonały projektant, ale raczej jak majsterkowicz-ślepiec czy majsterkowicz-amator. ${ }^{29}$ Neil Shubin, wybitny paleontolog i ewolucjonista, tak wprowadza opis człowieka: „Zacznijmy od ryby z jej specyficznym planem budowy, ubierzmy ją w kostium ssaka, a potem wymodelujmy tego ssaka tak, by stał

28 Szerzej zob. np. N. S h u b i n, Nasza wewnętrzna menażeria. Podróż w głąb 3,5 miliarda lat naszych dziejów, Prószyński i S-ka, Warszawa 2009.

${ }_{29}$ Szerzej J. W e i n e r, Dziób zięby, czyli jak dziś przebiega ewolucja, Książka i Wiedza, Warszawa 1997; J. M a y n a r d - S m i t h, E. S z a t h m a r y, Tajemnice przełomów w ewolucji, PWN, Warszawa 2000; J.A. C o y n e, Ewolucja jest faktem, Prószyński i S-ka, Warszawa 2009. 
na dwóch nogach, mówił, myślał i potrafił precyzyjnie manipulować palcami - i mamy gotowy przepis na kłopoty". ${ }^{30}$ Wykazuje, że dobór naturalny nie jest przewidującym inżynierem, który projektuje idealnie przystosowane do środowiska organizmy. Tworzy je z tego, co ma akurat pod ręką, i w każdym z nich zostawia rozmaite niedoróbki, które zostały odziedziczone po przodkach przystosowanych do zupełnie innego środowiska i stylu życia (tzw. niszy ewolucyjnej). Dotyczy to również człowieka. Inny znakomity biolog ewolucyjny, Francesco Ayala, pisze: „Ewolucja odpowiada na potrzeby organizmu przez dobór naturalny, a więc nie na drodze optymalnego projektu, ale poprzez majsterkowanie czyli powolną modyfikację zastanych struktur. (...) Projekt natury jest często tak niefunkcjonalny, dziwaczny i okrutny, że mógłby być przypisany bogom starożytnych Greków, Rzymian czy Egipcjan, którzy walczyli ze sobą, popełniali błędy i byli niezdarni w swoich poczynaniach”. Jest to powtarzana wśród biologów konstatacja, że jeśli natura jest tworem Boga i Jego śladem, to przypomina On raczej małostkowych bogów starożytnej Grecji niż doskonałego, wszechmocnego i dobrego Stwórcę. Wśród naukowców największy odsetek ateistów notuje się właśnie wśród biologów. Richard Dawkins w Rzece genów tak opisuje okrucieństwo wpisane w naturę: „Całkowita ilość cierpień będących co roku udziałem wszystkich żywych stworzeń przekracza wszelkie wyobrażenie. W ciągu minuty, jaką zajęło mi napisanie tego zdania, tysiące zwierząt zostało zjedzonych żywcem, tysiące uciekało przed śmiertelnym niebezpieczeństwem umierając ze strachu, tysiące było powoli drążonych od środka przez pasożyty, tysiące umierało w koszmarnych mękach z głodu, pragnienia i choroby". ${ }^{31}$ George Carlin, wyliczając nieszczęścia naszego świata, powiedział: „Jeśli to jest najlepsze, co mógł stworzyć wszechmogący Bóg, to nie jestem zachwycony.

\footnotetext{
30 N. S h u b i n, Nasza wewnętrzna menażeria, s. 11.

31 R. D a w k i n s, Rzeka genów. Darwinowska wizja życia, tłum. M. J a n n a s z, Wydawnictwo Cis, Warszawa 1995, s. 191n.
} 
To raczej przypomina robotę sezonowego wkurzonego urzędnika niż kochającego ojca. Świat to nie jest dobre CV dla Boga". ${ }^{32}$

Zapewne twierdzenie, że natura świadczy o istnieniu i dobroci Boga było prostsze kiedyś niż dziś. Obecnie jasne jest, że struktura świata biologicznego wyłaniana przez ewolucję i dobór naturalny nie osiąga optimum. Przyroda jest na wielu miejscach felerna, działa przeciw sobie i popełnia liczne błędy. Taki jest design świata. Ksiądz Heller stwierdzi: „Ewolucja nie prowadzi wprost do wniosku o istnieniu Boga" 33 i „W ewoluującym świecie istnienie cierpienia jest strukturalną koniecznością, ${ }^{34}$ To samo mogą powiedzieć fizycy o ewolucji wszechświata: kolizyjne kursy ciał niebieskich i ich zderzenia, ${ }^{35}$ olbrzymia liczba zniszczonych gwiazd, planet i galaktyk, fakt, że nasze Słońce przy końcu swego życia spali się, zagotuje oceany, wypali naszą planetę i wybuchnie; wcześniej prawdopodobnie nasza galaktyka (Droga Mleczna) zderzy się z większą galaktyką Andromedy; fakt że świat rozszerza się coraz szybciej zmierzając do rozproszenia i pustki, bezczasowego rozwodnienia - nie wskazują na doskonałego Projektanta, lecz na chaotyczność i przypadkowość procesu ewolucyjnego. Wszechświat nie jest stworzony dla nas, zupełnie się nami nie przejmuje. Nauka uświadamia, że nie jesteśmy miarą wszechrzeczy, a wszechświat wcale nie musi się dostosowywać do tego, co uważamy za możliwe, wygodne czy dobre. Nie jesteśmy wyróżnieni w kosmosie. Świat badany przez nauki przyrodnicze wyłania się jako niecelowy, co Steven Weinberg, fizyk i noblista, ujął w słynnym

32 Zob. https://www.youtube.com/watch?v=TLgacbYRQ_I (dostęp: 20 II 2016).

33 M. Helle r, T. P a bj a n, Stworzenie i początek wszechświata. Teologia - filozofia - kosmologia, Copernicus Center Press, Kraków 2013, s. 142; zob. też M. H e 11 e r, J. Ży c i ń s k i, Dylematy ewolucji, Biblos, Tarnów 1996, passim.

34 M. He 11 e r, Sens życia i sens wszechświata, Copernicus Center Press, Kraków 2014, s. 176. Ks. Heller sugeruje, że cierpienie jest ceną za złożoność organizmów. Bez wrażliwości na ból złożone organizmy (takie jak ludzie) miałyby małą szansę na przetrwanie, bo np. nie uciekałyby przed zagrożeniem.

35 Jedno z najbardziej spektakularnych znanych zderzeń to tzw. Gromada Pandory, czyli system Abel 2744 - kolizja przynajmniej czterech gromad galaktyk. Ma wielkość 5,9 mln lat świetlnych i leży ok. 3,5 mld lat świetlnych od Ziemi. 
zdaniu: „Im bardziej wszechświat wydaje się nam zrozumiały, tym bardziej także wydaje się bezsensowny" ${ }^{36}$ Ksiądz Heller, konstatując podobnie, przedstawia to jednak w perspektywie odwróconej: „Być pionkiem w grze, której się nie rozumie, i to pionkiem tak bardzo kruchym, jest czymś deprymującym. Gry nie można zmienić, ale czy można ją przynajmniej zrozumieć?" "37

Czy w takim razie da się obronić biblijny argument za istnieniem i doskonałością Boga czerpany z obserwacji natury? Czy „z wielkości i piękna stworzeń rzeczywiście poznaje się przez podobieństwo ich Stwórcę”? Czy istotnie ,głupi są wszyscy ludzie, którzy nie poznali Boga" (Mdr 13,1; por. Ps 14,1; 53,1)? Pomijam tu zasadniczą kwestię teodycei, czyli obrony pojęcia dobrego i wszechmocnego Boga w konfrontacji z istnieniem zła i cierpienia. Skupię się tylko na biblijnym argumencie, że z obserwacji natury można - i należy! - poznać, że Bóg istnieje. Wydaje się, że potrzeba szerzej spojrzeć na cały problem. Próba skonfrontowania tych dwóch pozornie wykluczających się wizji idzie, moim zdaniem, po linii podniesienia biblijnego rozumowania na wyższy poziom, czyli szukania śladów Boga nie w konkretnych fenomenach przyrody i świata - może się bowiem słusznie wydawać, że Bóg nie zostawia śladów w przyrodzie - ale w świecie jako całości. I po tej linii idzie rozumowanie ks. Michała Hellera. Świat i jego natura nie jest wroga człowiekowi. Kosmos przekonał nas, że jego głęboka struktura ma w sobie coś przyjaznego: pozwala się rozumieć. Fizykom czy kosmologom łatwiej niż biologom przychodzi kontemplacja racjonalności czy harmonii wszechświata - czy to pod wpływem niewątpliwego uroku samego kosmosu, czy ze względu na swoiste piękno ukryte w teoriach matematycznych i ich

36 „The more the universe seems comprehensible, the more it also seems pointless". Jest to ostatnie zdanie epilogu książki S. W e i n b e r g, The First Three Minutes. A Modern View of the Origin of the Universe; po polsku wydanej jako: Pierwsze trzy minuty, Prószyński i S-ka, Warszawa 1998.

37 M. He 11 e r, Racjonalność i sens. Wykład wygłoszony z okazji przyznania doktoratu honoris causa Uniwersytetu Śląskiego. Katowice, 11 marca 2015 r., Tygodnik powszechny z 21 III 2015; https://www.tygodnikpowszechny.pl/racjonalnosc-i-sens-27142 (dostęp: 21 II 2016). 
odzwierciedleniu w realnym świecie. W cytowanym już wystąpieniu, ks. Heller stwierdza: „Uważam, że racjonalność Wszechświata, ten zadziwiający i «niezrozumiały» fakt, iż Wszechświat daje się rozumieć, dostarcza - pośredniego, zapewne, ale wymownego - argumentu za sensownością ludzkiego istnienia. Jeżeli nie odwołamy się do pomocy religii, to nadal nie wiemy, co jest tym sensem, ale domyślamy się, że żyjemy w środowisku Racjonalności i Sensu". ${ }^{38}$ W podobnym duchu, choć jako zdeklarowany ateista, wypowiedział się astrofizyk i noblista Subrahmanyan Chandrasekhar: „Niesamowity fakt, że odkrycie spowodowane szukaniem piękna w matematyce znajduje swoje dokładne odbicie w Naturze przekonuje mnie, że piękno jest tym, na co ludzki umysł reaguje w sposób najgłębszy i najbardziej wnikliwy".

Okazuje się więc, że „ślady Boga” dostrzec można w postrzeganiu świata jako całości, w samym fakcie jego istnienia (słynne pytanie Leibniza: Dlaczego istnieje raczej coś niż nic?) i w jego najgłębszej strukturze. Nie jest to jednak argument za istnieniem Boga, który trafi do wszystkich. Świat jest otwarty na różne interpretacje, a nauka nie determinuje takiego czy innego światopoglądu. Dziś zatem nie posługiwałbym się już argumentem z natury za istnieniem Boga, ale także nie wyciągałbym z nauki wniosków przeciwnych. Zarówno ci, którzy dowodzą istnienia Boga, jak i ci, którzy temu zaprzeczają, wykorzystując do tego naukę, posługują się nią niezgodnie z jej właściwym celem i kompetencjami. Czy można winić biologów, że, opisując zjawiska natury, nie dostrzegają w niej piękna Bożego planu, ale ślepy i okrutny dobór naturalny? Jedni widzą w świecie harmonię i sens, zamysł i racjonalność, inni chaos, bezcelowość i przypadek. Nauka dostarcza jedynie faktów. To po naszej stronie jest to, co widzimy, jak interpretujemy fakty i jaki tworzymy światopogląd, a nie

38 Tamże. Dla Michała Hellera „Racjonalność” (koniecznie przez wielkie „R”) jest ,imieniem ukrytego Boga”. Świat przyrody opisywany w języku matematyki wyraża, jego zdaniem, harmonię stworzenia, w której objawia się „Logos Stwórcy”; zob. J. Ż y c i ń s k i, Bóg i stworzenie. Zarys teorii ewolucji, Wyd. Gaudium, Lublin 2011, s. 117. 
po stronie świata. Argument z piękna stworzenia za istnieniem Boga ma zatem charakter względny, subiektywny.

Do rozważenia dla ludzi wierzących pozostaje pytanie, dlaczego Bóg stworzył świat ewolucyjnie tak, że nie jest On w nim ewidentny. Najpopularniejsza odpowiedź jest taka, że jeśli Bóg chciał stworzyć świat ludzi wolnych i w wolności wybierających lub odrzucających Boga, to prawdopodobnie nie miał do wyboru wielu innych koncepcji stworzenia od tej, którą faktycznie zrealizował. ${ }^{39}$ Gdyby Bóg stworzy świat nie przez ewolucję, ale bezpośrednim aktem i zostawił w nim swe ewidentne ślady, nie dałby człowiekowi miejsca na wiarę, a zatem na wolną wolę i miłość. To uzasadnienie nazywa się argumentem ze skrytości Boga: oczywistość istnienia Boga miałaby bardzo silny wpływ na nasze wybory i uniemożliwiałaby wiarę. Zbliżony pogląd wyraża ks. Heller - istnieje jakaś strukturalna konieczność, której musi podporządkować się Bóg, że świat wygląda tak, a nie inaczej. Według niego to sam Bóg jest tą koniecznością, gdyż nie może zaprzeczyć sobie i celowi, w jakim stworzył świat. ${ }^{40}$

Są też inne ciekawe propozycje filozoficzne, np. autonomia świata (aksjologicznie większa wartość niż całkowita zależność); kenotyczna wizja Boga (Bóg ograniczył swą władzę, pozostawił naturę niezdeterminowanemu działaniu jej samej); koncepcja logiczności obrazu Boga i świata (wszechmocy stwórczej Boga nie można pojmować tak, jakby Bóg mógł wszystko stworzyć doskonale i usunąć dowolne elementy świata - np. ewolucję, zło - jednocześnie gwarantując mu indeterminizm, wolność, wolę i swe ukrycie. Bóg nie może zaprzeczyć sobie i prawom logiki); koncepcja wyrafinowanego projektu (tak wyrafinowana i skomplikowana forma ewolucji świata jest ciekawsza i bardziej ,przystoi” majestatowi i tajemnicy Boga); koncepcja solidarności stworzenia (biblijne „,z prochu powstałeś” oznacza materię wszechświata, co czyni nas spokrewnionymi nie tylko ewolucyjnie ze wszystkimi istotami żywymi, ale dzięki materii z całym kosmosem).

39 J. W e r b i c k, Wprowadzenie do epistemologii teologicznej, tłum. G. R a w s k i, WAM, Kraków 2014, s. 269n.

${ }_{40}$ M. He 11 e r, Sens życia i sens wszechświata, s. 176n. 
Każda z tych koncepcji ma ciekawe rozwinięcia, ale także napotyka istotne aporie, nie miejsce tu jednak na ich analizę.

\section{Dzialanie Boga w świecie: Czy istnieją cuda?}

To chyba jedna z najtrudniejszych kwestii na styku Biblii i współczesnej nauki. Pismo Święte niemal na każdej stronicy relacjonuje działanie Boga w świecie, w życiu konkretnych ludzi, rodzin i całych narodów. Przedstawia boskie interwencje, cuda, uzdrowienia, plagi, nadzwyczajne poczęcia, wskrzeszenia, ingerencje w prawa przyrody itp. Bóg Biblii działa w świecie, objawia się i odpowiada na modlitwy. Takie jest też sententio communis ludzi wierzących: Bóg spełnia niektóre prośby, czyni czasem cuda, interweniuje w wybranych przypadkach. Świat religijny jest bogaty w cuda. Kościół jest tu powściągliwy i ostrożny, jednak potwierdza wiarę w nadnaturalną (praeternaturalis) cudowność pewnych zdarzeń, np. w kryteriach procesów beatyfikacyjnych i kanonizacyjnych, w których oczekuje nadzwyczajnego i niewytłumaczalnego cudu zdziałanego przez Boga za wstawiennictwem badanej osoby.

Wobec wiary w obiektywne cuda współczesna nauka jest bardzo krytyczna. Przyczyna tego jest prosta: nauka niczego takiego nie obserwuje. Wszystkie zjawiska opisywane jako cudowne albo już jest w stanie wyjaśnić, albo ma poważne przesłanki do tego, że za jakiś czas uda jej się to wyjaśnić w sposób naturalny, przyczynami i prawami fizycznymi. ${ }^{41}$ I trzeba przyznać, że odnosi tu niebywałe rezultaty. Sukces nauki oparty na metodzie deterministycznej- mówiącej, że fizyczna przyczyna ma fizyczny skutek - jest tak wielki, że dziś zakłada się, iż przyroda domyka się przyczynowo. Innymi słowy wszystko, co fizycznie obserwujemy w świecie, ma przyczynę

${ }^{41}$ Piszę o prawach fizyki, a nie np. biologii czy psychologii, gdyż to do praw fizyki - stosując zasadnicze uproszczenie - sprowadzają się prawa innych nauk (redukcja psychologii do biologii, biologii do chemii, chemii do fizyki. Fizyka redukuje się już tylko do matematyki, ale ta nie jest nauką empiryczną i nomotetyczną, lecz formalną). 
fizyczną, materialną. Jest to fundamentalna reguła, niejako kamień węgielny metody naukowej, która nazywa się domknięciem kauzalnym, domknięciem przyczynowym. Według niej żadne zdarzenie fizyczne nie ma przyczyny poza światem fizycznym i w jego wyjaśnianiu nie należy się nigdy poddawać. Stwierdzenie nadprzyrodzoności jakiegoś zjawiska byłoby skrępowaniem nauki, kapitulacją umysłu i zaprzeczeniem metody naukowej. Wyjaśnialne fakty można by zacząć oceniać jako nadprzyrodzone, zaprzeczając rozumowi i racjonalności ludzkiej. Dlatego warunkiem uprawiania nauki jest poszukiwanie racjonalnych przyczyn wszystkich zdarzeń, które jak dotąd przynosi niezwykłe osiągnięcia, dla religii nie zawsze jednak wygodne. Wydarzenia niezwyczajne, o których ludzie religijni twierdzili, że są nadprzyrodzonym działaniem Boga, okazują się prędzej czy później możliwe do wyjaśnienia naturalnego, wytłumaczalne przyczynami fizycznymi. Historia nauki dowodzi tego w sposób trudny do zakwestionowania. Wystarczy przytoczyć przykłady takie, jak tęcza (zjawisko przez tysiąclecia uważane za nadprzyrodzone), uzdrowienia z cholery (kiedyś uważane za cudowne i przypisywane Bogu/świętym, dziś wiemy, że cholera jest uleczalna), z padaczki (długo uważanej za rodzaj opętania) czy zjawiska towarzyszące śmierci klinicznej (tzw. near-death experiences), jak oglądanie własnego ciała, światła, tunelu itd., które coraz lepiej wyjaśniają neuronauki. Twierdzenie, że coś ma charakter nadprzyrodzony tylko dlatego, że nauka jeszcze nie do końca potrafi to wyjaśnić, wydaje się stać na zagrożonej, jeśli nie z góry przegranej, pozycji. Owszem, wyjaśnianie zjawisk świata przyczynami nadprzyrodzonymi lub magicznymi jest znacznie prostsze i zawsze znajdowało i będzie znajdować swoich zwolenników, jednak w starciu z nauką, odkąd ukształtowała się jej nowoczesna metodologia, zmuszone jest ciągle ustępować pola.

Jak zatem $w$ teologii traktować to zderzenie wiary $w$ cuda $\mathrm{z}$ jednej strony z metodą naukową z drugiej? Stanowiska są dwa. Pierwsze $\mathrm{z}$ nich to teizm tradycyjny, reprezentowany przez większość ludzi wierzących. Jest on oparty na nadnaturalizmie (istnieje Bóg oraz inne byty nadnaturalne: anioły, dusza, czyściec itd.) oraz na 
interwencjonizmie (Bóg i inne istoty nadnaturalne ingerują w świat, często wbrew prawom przyrody). Drugie podejście to teizm naturalistyczny (inne nazwy to naturalizm teistyczny, naturalizm chrześcijański, ewolucjonizm teistyczny), reprezentowany np. przez współpracownika Darwina, Asę Graya (prezbiterianizm), genetyka Theodosiusa Dobzhanskiego (prawosławie), biologa Kennetha Millera (katolicyzm), genetyka Francisa Collinsa (ewangelikalizm), genetyka Roberta Jamesa Berry (anglikanizm), paleontologa Simona Conway Morrisa (anglikanizm) czy niektórych laureatów nagrody Templetona, a w Polsce przez ks. Michała Hellera czy abp. Józefa Życińskiego. Ten światopogląd chce godzić wiarę z nauką. Zgadza się nie tylko na odkrycia naukowe, ale i na metodologię naukową, czyli na naturalizm metodologiczny - doszukiwanie się we wszystkim zjawisk naturalnych - choć nie godzi się na naturalizm metafizyczny. ${ }^{42}$

W interwencjonizmie (teizmie tradycyjnym) mowa jest o dwóch rodzajach działania Boga: ogólnym i szczególnym. Ogólne (zwyczajne) to działanie Boga Stworzyciela: Bóg stworzył świat (creatio ex nihilo), prawa fizyki i podtrzymuje go w istnieniu (creatio coninua). Szczególne (nadzwyczajne) natomiast to interwencyjne i kontrnaturalne działanie Boga w stworzonym świecie (np. cuda). Interwencjonizm dopuszcza to, że Bóg może łamać czy uchylać prawa przyrody, albo działać ponad prawami, które sam ustanowił. Na trudne filozoficznie pytania - Jak Bóg może działać wbrew prawom, które sam stworzył? Czy może zaprzeczać sobie i podkopywać zaufanie do samego siebie, że stworzył coś dobrego, czego nie trzeba poprawiać? - interwencjonizm odpowiada tezą, że Bóg jest suwerennym Panem praw natury, które stworzył, a Jego wszechmoc nie ma żadnych granic. Może więc łamać wcześniej ustalone zasady. Odwołuje się też do danych biblijnych i do tego, że Bóg w ramach historii zbawienia wielokrotnie podejmował działania cudowne, niezgodne z porządkiem naturalnym.

42 Szerzej zob. N. S h a n k s, God, The Devil, and Darwin. A Critique of Intelligent Design Theory, R. D a w k i n s (przedmowa), Oxford University Press, Oxford 2004, passim; M. H e 11 e r, J. Ż y c i ń s k i, Dylematy ewolucji, s. 153-172. 
Nieinterwencjonizm (teizm naturalistyczny) z kolei zakłada, że działania Boże nie naruszają praw przyrody, czyli ani ich nie łamią, ani nie uchylają. W teologii naturalistycznej mówi się, że Bóg stara się nie wtrącać, nie ingerować, nie wymuszać sprzeczności w prawach. Działa w ich ramach, w ich wnętrzu, a nie przeciw nim. Arcybiskup Życiński na swych wykładach powtarzał, że dzisiaj rozumienie działania Boga jako interwencji w bieg praw przyrody jest nie do utrzymania. Raczej należy iść w kierunku podejść nieinterwencjonistycznych. Bóg nie musi interweniować z zewnątrz, bo jest obecny immanentnie w tym, co istnieje. Transcendentny Bóg jest obecny w prawach przyrody, a nie przeciw nim. Zgadza się z nim ks. Heller, który twierdzi, że nie ma (nie obserwuje się) cudów rozumianych jako łamanie praw przyrody: „Bóg nie działa przez antynaturalistyczne pchnięcia”. Choć nie wyklucza działania Boga na zupełnie innym, niedostępnym i nieznanym nam poziomie struktury świata. Oczywiście naturalizacja nie musi przekreślać teistycznej interpretacji zjawisk. Można sobie bowiem wyobrazić, że Bóg działa przez prawa przyrody, a nie wbrew nim. Do interpretacji nieinterwencjonistycznej zbliża się jedna z najważniejszych tradycji judaizmu. Według kontynuatorów myśli Hillela, Bóg pozostawił człowiekowi wolność i pilnie baczy, by się w sprawy ludzkie nie mieszać. Znany żydowski egzegeta Israel Knohl pisze: „Szkoła Hillela reprezentuje tendencję - można ją nazwać racjonalistyczną - szukającą autonomii dla człowieka na ziemi: «Niebo jest niebem Pana, synom zaś ludzkim dał ziemię» (Ps 115,16). Niebo nie może interweniować w to, co dzieje się na ziemi". ${ }^{43}$

Obydwa stanowiska nie są wolne od kłopotliwych pytań. Teizm tradycyjny nie jest w stanie wytłumaczyć, dlaczego notuje się „,cudowne" uzdrowienia z nowotworów, ${ }^{44}$ a nie notuje się odrastania

43 I. K n o h 1, The Divine Symphony. The Bible's Many Voices, Jewish Publication Society, Philadelphia 2003, s. 143.

${ }^{44}$ Choroby do dziś nie poznanej, a zatem przed nauką stoi tu wiele możliwości wyjaśnienia tych zjawisk. Świadoma tego Kongregacja ds. Kanonizacyjnych w Rzymie zdecydowała się nie przyjmować w procesach kanonizacyjnych udokumentowanych „cudów” remisji różnego rodzaju nowotworów, np. białaczki. Wydaje się, że to bardzo słuszna decyzja, bowiem pojęcie remisji - cofnięcia się choroby 
amputowanych kończyn; dlaczego w katastrofie, w której ocalało jedno dziecko - co określa się w kategorii cudu - inne dzieci zginęły. Ten drugi przykład jest dla Maurice'a Wilesa powodem do odrzucenia wiary w cuda, ale nie z logicznego, lecz z moralnego punktu widzenia. Ten kapłan anglikański i profesor Oxfordu twierdzi, że wiara w Boga, który uzdrowił kogoś, sprawił, że statuetka Matki Bożej zaczęła płakać krwią, słońce zawirowało czy zadziałał w inny względnie trywialny sposób, a jednocześnie pozwolił na Holokaust, Rwandę, trzęsienia ziemi, tsunami i ocean innych cierpień ludzkości, jest absurdalna z punktu widzenia filozofii moralności. Bóg, który pomnaża wino w Kanie, by zapobiec konsternacji weselników i przedłużyć zabawę, a nie reaguje na prawdziwe dramaty i tragedie, jego zdaniem nie jest godny czci, bowiem nie może być moralny i dobry. Autor opowiada się zatem za koncepcją nieinterwencjonistyczną. ${ }^{45}$ Problem z cudami w teizmie tradycyjnym jest też taki, że wydarzenia cudowne - nie do wyjaśnienia na obecnym etapie nauki - zdarzają się we wszystkich religiach i kulturach, niezależnie od wiary i niewiary w osobowego Boga, często umacniając przekonania i przesądy niezgodne z obrazem biblijnym. Powszechność i podobne statystyczne rozłożenie zjawisk niewyjaśnialnych w świecie (w różnych cywilizacjach i religiach) sugerują słuszność interpretacji naturalistycznej.

$\mathrm{Z}$ kolei teizm naturalistyczny mierzy się z właściwym ujęciem obrazu Boga. Bóg teologów ewolucyjnych albo w ogóle nie ingeruje w świat (forma deizmu), albo staje się Bogiem immanentnym, działającym wewnątrz praw świata (forma panteizmu) - a więc nie transcendentnym Stwórcą wiary chrześcijańskiej. W pracach i wystąpieniach teologów ewolucyjnych brak odniesień do takich tematów jak anioły, demony, opętania, stygmaty, czyściec, widzenia itp., a rozróżnienie tego, co naturalne i nadnaturalne, zostaje rozmyte. Wszystko sprowadza się do

lub okresu charakteryzującego się brakiem objawów chorobowych - stosuje się zwłaszcza wobec chorób i zaburzeń, w których nie można zdefiniować wprost, co oznacza „wyleczenie”. Po stwierdzeniu „cudownego” zaniku choroby może się okazać, że za kilka czy kilkanaście lat choroba powróci.

45 Zob. M. W i l e s, God's Action in the World, SCM Press, London 1986. 
ukrytego działania Bożej immanencji w świecie praw przyrody. Bardziej konsekwentni i skrajni teolodzy procesu uznają za symboliczne nie tylko wszystkie cuda ewangeliczne, ale także zmartwychwstanie Chrystusa.

Jak zatem chrześcijanin powinien podejść do zjawiska cudu? Wyobraźmy sobie pacjenta umierającego na raka. Choć lekarze robią wszystko, co w ich mocy, nie mają dla niego dobrych rokowań. Są przekonani, że pacjent nie przeżyje kilku miesięcy. Jednak wbrew pesymistycznym przewidywaniom terapia zaczyna działać i rozpoczyna się remisja nowotworu. Przyczyny nagłej poprawy zdrowia mogą być całkowicie naturalne, ale z perspektywy wierzącego pacjenta odzyskanie zdrowia jest cudem. Jest on tym bardziej o tym przekonany, że $\mathrm{w}$ tym czasie jego rodzina zanosiła żarliwe modlitwy. ${ }^{46}$ Wiara w boskie ingerencje nie musi opierać się na zjawiskach nadprzyrodzonych czy kontrnaturalnych. Cuda są kwestią interpretacji zjawisk. Cudem są narodziny długo oczekiwanego dziecka. Cud jawi się tu jako kategoria subiektywna (dla mnie coś jest wydarzeniem cudownym). W niektórych sytuacjach taką interpretację mogą wspierać pewne korelacje, np. małżeństwo wraca do siebie po okresie żarliwej modlitwy. Jest to cud z subiektywnego, nie obiektywnego, punktu widzenia. Twierdzenia o boskiej interwencji najczęściej dotyczą zdarzeń, odnośnie do których mamy niewielkie możliwości przewidywania i kontroli, takich jak pogoda, sport, zdrowie czy rodzinne i społeczno-ekonomiczne interakcje między ludźmi. Za to niezmiernie rzadko są wysuwane odnośnie do tych rzeczy, dla których możemy dokładnie przewidywać i testować wyniki, jak ruch ciał niebieskich, punkt wrzenia wody, przyciąganie grawitacyjne czy zmiana jednej rzeczy w inną. Amputowane kończyny nie odrastają, góry się nie przesuwają, a jedzenie nie pojawia się przed głodującymi dziećmi. Jeśli Bóg jest zmuszony bezustannie interweniować we wszechświecie, który stworzył, robi to w taki sposób, że jest to nieodróżnialne od zjawisk naturalnych, możliwych, wyjaśnialnych, losowych bądź takich, co do których nauka ma nadzieję na ich wyjaśnienie. Ta interpretacja

46 Przykład zaczerpnięty z Ł. K w i a t e k, Racjonalność przez duże „R”, https:// www.naukaireligia.pl/racjonalnosc-przez-duze-r-25336 (dostęp: 21 II 2016). 
teologiczna zmierza w kierunku uznania subiektywnej wartości cudu. Co jednak z obiektywnym działaniem Boga w świecie materii (nie poruszam kwestii działania Boga w świecie ducha)?

Tu dochodzimy do stanowiska poniekąd pośredniego między teizmem tradycyjnym a naturalistycznym, którego dostarcza zagadnienie tzw. opatrzności kwantowej. Ponieważ zjawiska kwantowe są w pewnej mierze niedookreślone i niemożliwe do przewidzenia $\mathrm{w}$ ramach znanych praw i matematycznie wyznaczonych granic - to właśnie w nich poszukuje się możliwych interwencji Bożych, które nie zakłócą praw fizyki, a jedynie wykorzystają ich niezdeterminowanie do wpływu na określone zjawiska. Zwolennicy tej teorii twierdzą, że Bóg interweniuje, ale nie wbrew naturze i jej prawom, lecz tam, gdzie przyroda pozostawia elastyczność, przypadek i indeterminizm - właśnie na poziomie kwantów. Dlatego wiadomo np. o co można Boga prosić, a o co nie ma sensu prosić. Na przykład nie można się modlić o zmianę pór roku, o wstrzymanie słońca: ruch układu słonecznego jest mechaniczny, stały, stabilny, na jego podstawie tworzy się kalendarze, tablice astronomiczne i ustala czas, więc $w$ tej materii nie ma szans na działanie Boga. Ale już o pogodę, która jest zjawiskiem ogromnie złożonym, tak. Ksiądz Michał Heller jest krytykiem tej koncepcji, gdyż powiela ona jego zdaniem teologiczny błąd „Boga dziur” (God of the gaps). Wybiera on inną, holistyczną drogę rozumienia działania Boga w świecie, którą nazywa tezą monistyczną: „Działanie Boże nie ujawnia się w naturalnym biegu świata nie dlatego, że Jego działania tam nie ma, ale dlatego, że cały naturalny bieg świata jest Jego działaniem". ${ }^{47}$

Poszukiwanie cudów i cudowności towarzyszy religii od zawsze i jest ważnym elementem zwłaszcza prostej pobożności. Takiej religijności nie interesują niuanse i pogłębienia, ona chce wiedziéć, że Bóg jest, potrzebuje cudu. Już św. Augustyna bardzo niepokoiła skłonność ludzi do wiary w cuda. Obserwując magiczne myślenie i zabobonność pielgrzymów, mawiał zrezygnowany: „Czego innego

${ }_{47}$ M. He 11 e r, Sens życia i sens wszechświata, s. 147. 
nauczamy, a co innego musimy tolerować". ${ }^{48}$ To z jego inicjatywy powstały pierwsze w Kościele zachodnim miracula, czyli zbiory cudów, w których autorzy dużą wagę przykładali do eliminowania elementów magicznych w opowieściach o uzdrowieniach. Współczesna teologia wrażliwa na postęp nauki także zaleca wielką ostrożność w interpretacji zjawisk cudownych.

\section{Czy religia jest źródłem moralności?}

Bardzo rozpowszechniony jest pogląd, że moralność mamy dzięki religii, a jej pierwszym zasadniczym źródłem jest Biblia, że o tym, jak postępować i co jest dobre, a co złe, mówi nam Boże objawienie: bez religii i bez Boga (czytaj: bez Biblii) nie wiedzielibyśmy, co jest dobre, a co złe. Pogląd ten wymaga korekty i pogłębienia w świetle współczesnej wiedzy o człowieku. Pytanie o źródła moralności i o to skąd pochodzą normy etyczne jest pytaniem starym jak sama filozofia. Nie będę rozważał tego problemu całościowo, lecz w dwóch ostatnich punktach skupię się na pytaniu, czy i w jakiej mierze religia i Biblia są źródłami moralności.

Skąd wiemy, że pewne rzeczy należy czynić (np. oddać dług), innych rzeczy nie należy czynić (np. zadawać bezsensownego cierpienia). Jak to się dzieje, że istnieją zachowania, na które nie pozostajemy obojętni? ${ }^{49}$ Dlaczego za pewne zachowania chcemy karać? ${ }^{50}$ Skąd wiemy, że zło jest złem? Filozofia wypracowała trzy główne grupy odpowiedzi: 1. Dochodzimy do tego na drodze rozumowania (racjonalizm, np. Kant i jego imperatyw kategoryczny). 2. Nauczyli nas tego

48 Cyt. za: M. M ü 11 e r, Szczyt ginący w chmurach, czyli opowieść o relikwiach, List 6/2015, s. 16n.

49 Np. gdy usłyszymy zdanie: „Gram na pianinie słabo, ale chcę tak grać, mi to wystarczy" - to nie oburzy nas taka postawa, ostatecznie stwierdzimy, że każdy ma do niej prawo. Ale jeśli usłyszymy zdanie: „Kradnę, ale chcę i będę tak kraść” - to trudno nam pozostać wobec takiej postawy zupełnie obojętnym.

50 Mamy w sobie taki mechanizm, że chcemy karać nawet wtedy, gdy czyn nas w ogóle nie dotyczy, i nawet wtedy, gdy mamy się przez to narazić lub coś stracić. Karanie jest zatem altruistyczne. Dobre dla społeczeństwa, ale szkodliwe dla karzącego. 
inni: rodzice, wychowawcy, społeczeństwo, religia (empiryzm). 3. Czujemy to intuicyjnie, po prostu to wiemy, rodzimy się z tym (natywizm). Biblia jako źródła moralności mieści się w grupie drugiej: uczymy się, jak postępować z przesłania Biblii i przykładu życia jej bohaterów.

Okazuje się jednak, że normy nie biorą się z zewnątrz, lecz tkwią w nas samych. Ogromna liczba eksperymentów z najmłodszymi dziećmi potwierdziła, że instynkt moralny jest wrodzony, pojawia się, zanim dziecko nauczy się mówić czy odbierze wychowanie w jakiejkolwiek dziedzinie. Zastanówmy się: gdy pożyczymy od koleżanki pieniądze, to jest jakoś oczywiste, że powinniśmy jej je oddać. Podobnie oczywiste jest to, że rodziców mamy szanować, rannego opatrzyć, a tonącemu starać się jakoś pomóc. Nie potrzeba nas tego uczyć, ani do tego przekonywać. Ta zadziwiająca samooczywistość, bezpośredniość i apodyktyczność nakazów moralnych zastanawiała myślicieli od dawna. Etyka jest nią wprost oczarowana. Kiedy bowiem próbujemy je tłumaczyć, kiedy szukamy dla nich powodów i racji, to narażamy się jedynie na ich relatywizację, na dyskusję i możliwość obalenia takiego czy innego uzasadnienia. ${ }^{51}$ Tymczasem długi się oddaje, tonących próbuje ratować, a śpiącej matce nie podcina się gardła. Skąd zatem to wiemy?

To, że uważamy coś za moralnie obowiązywalne, nie zawdzięczamy Biblii, religii, wychowaniu czy prawu, ale nam samym. To jest nasze dziedzictwo ewolucyjne. Nasze decyzje i sądy moralne biorą się z instynktów moralnych - jak skłonność do współpracy, poczucie sprawiedliwości, troska o potomstwo czy lojalność wobec grupy - które uformowały się w toku tysięcy lat ewolucji i są w nas osadzone bardzo głęboko. Instynkty moralne wywołują emocje moralne, które są rodzajem silnego motywatora, sprawiają, że działamy tak, a nie inaczej, i oceniamy coś jako dobre lub złe, często w sposób natychmiastowy. Emocje moralne są pierwsze, automatyczne i przedrefleksyjne, nie ustanawiają powinności moralnych, ale przekazują

51 Dodatkowo uzasadnienie naszych intuicyjnych sądów moralnych może być niełatwe, ponieważ rozumowanie musi dopiero dostosować się do tych intuicyjnych, oczywistych, bezpośrednich sądów. 
intuicyjną wiedzę na ten temat. Dopiero wtórnie racjonalny umysł próbuje uzasadniać nasze działania lub odczucia, lepiej czy gorzej. Emocje moralne funkcjonują jak nasz wewnętrzny kompas, który pozwala nam szybko i mniejszym nakładem energii podejmować decyzje moralne. Nie oznacza to oczywiście, że wskazówka tego kompasu zawsze wskazuje (największe) dobro i że wyczerpują one zakres zachowań moralnych. Nasze uposażenie biologiczne wyznacza bazę, swoiste pole możliwości, w ramach którego tworzy się bardziej zaawansowane, oparte na rozumie normy postępowania, etykę ćwiczenia się w cnotach itd. Podstawą moralności zawsze jednak będą nasze instynkty moralne wytworzone w procesie doboru naturalnego. Zwane czasem głosem wewnętrznym czy głosem sumienia, każą nam postąpić tak, a nie inaczej, nawet gdy normy społeczne i prawne nakazują coś innego. Polecam na ten temat znakomite prace Patrycji Churchland, ${ }^{52}$ Fransa de Waala, ${ }^{53}$ Jonathana Haidta,${ }^{54}$ Robina

52 P. Chu r c h l a n d, Moralność mózgu. Co neuronauka mówi o moralności, tłum. M. Ho h o 1, N. M a r e k, Copernicus Center Press, Kraków 2013. Autorka omawia źródła moralności człowieka z punktu widzenia biologii, neuronauki i ewolucji. Podstawowe wartości, jak odpowiedzialność, troska o siebie, o potomstwo i najbliższych, skłonność do kooperacji, są owocem tysięcy lat ewolucji, która zakodowała je w naszym układzie nerwowym. Moralność ma swe źródło w neurobiologii przywiązania, opieki i kooperacji. W książce omawiane są także takie zagadnienia jak neurony lustrzane, geny a zachowania, imitacja, złota reguła, konsekwencjonalizm i utylitaryzm itd.

${ }^{53}$ F. d e W a l, Matpy i filozofowie. Skąd pochodzi moralność?, tłum. B. B roż e k, M. F u r m a n, Copernicus Center Press, Kraków 2013; t e n ż e, Bonobo $i$ ateista. W poszukiwaniu humanizmu wśród naczelnych, Copernicus Center Press, Kraków 2014; t e n ż e, Małpa w każdym z nas. Dlaczego seks, przemoc i życzliwość są częścia natury człowieka?, tłum. K. K o r n a s, Copernicus Center Press, Kraków 2015. Według de Waala, moralność to „rozwinięcie naturalnych zdolności społecznych". Podstawą moralności nie są logiczne rozumowania, kalkulacje czy też wyuczone podczas socjalizacji reguły, ale wykształcone ewolucyjnie emocje. Moralność wyrasta głęboko z naszej natury, która formowała się w trakcie długiej ewolucji Homo sapiens. Kooperacja jest zjawiskiem korzystnym, dlatego też proste formy moralności wspólne są również dla organizmów innych niż człowiek.

54 J. H a i d t, The Emotional Dog and Its Rational Tail. A Social Intuitionist Approach to Moral Judgment, Psychological Review 108/2001, s. 814-834. Haidt 


\section{Dunbara ${ }^{55}$ czy Michaela Tomasello, ${ }^{56}$ a także miejscami kontrower- syjną, ale ważną publikację Sama Harrisa, ${ }^{57}$ czy na gruncie polskim}

przekonuje, że należy odrzucić tezę, iż „wiedza moralna i sąd moralny osiągane są, przede wszystkim, na drodze rozumowania i refleksji”. Twierdzi, że sądy moralne są wynikiem pojawienia się działającej bardzo szybko intuicji moralnej, za którą czasem, choć nie zawsze, podąża relatywnie wolniejsze rozumowanie. Zdaniem Haidta tym, co prowadzi do negatywnej oceny, nie są racje rozumowe, ale oparty na emocjach „kompas moralny”. Jest to emocja, którą przeżywamy dosłownie całym ciałem, co prowadzi do automatycznego wydania osądu czy podjęcia działania. Emocje moralne nie są efektem wychowania czy przynależności kulturowej, ale zostały „zaprogramowane” w toku wielu tysięcy lat ewolucji. Nie oznacza to jednak, że warunkowany emocjami osąd nie może zostać wzmocniony np. przez przekonania religijne, kalkulacje zysków i strat czy wpojony w nas system wartości. Tego typu uzasadnienia są jednak tylko ogonem, którym merda emocjonalny pies - jakim w większości przypadków okazuje się nasz mózg.

${ }_{55}$ R. D u n b a r, Ilu przyjaciót potrzebuje człowiek? Na tropie tajemnic ewolucji, Wydawnictwo Literackie, Warszawa 2010. Autor wykazuje, że teoria umysłu (umiejętność przypisania innym myśli, pragnień, zamiarów) stała się podstawą empatii i złotej reguły moralności. Wskazuje, że religia oprócz nadawania światu spójności i zapewniania poczucia kontroli nad zjawiskami niekontrolowalnymi pełni ewolucyjną funkcję ustanawiania systemów moralnych i norm społecznych w celu spajania grupy i umacniania poczucia przynależności.

${ }_{56}$ M. To m a s e 11 o, Dlaczego współpracujemy, tłum. Ł. Kw i a t e k, Copernicus Center Press, Kraków 2015; t e n ż e, Historia naturalna ludzkiego myślenia, tłum. B. K u c h a r z k, R. O c i e p a, Copernicus Center Press, Kraków 2015. Autor twierdzi, że ludzie mogli stworzyć język, moralność, a nawet matematykę dzięki zdolności do wyznaczania i realizacji wspólnych celów, opartej na utożsamianiu się z przedstawicielami własnego gatunku. Przekonuje, że jesteśmy z natury skłonni do altruizmu, przejawiającego się w trzech wymiarach: dzielenia się z innymi żywnością, informacjami oraz niesienia im pomocy. Na pewnym etapie ludzie pierwotni zostali zmuszeni przez warunki naturalne do przejścia na tryb nastawiony w większym stopniu na współpracę. W wyniku tego ich procesy myślowe zorientowane zostały na wynajdywanie sposobów koordynowania pracy z innymi.

${ }_{57} \mathrm{~S}$. H a r r i s, Pejzaż moralny. W jaki sposób nauka może określać wartości, tłum. P.J. S z w a j c e r, Wydawnictwo CiS, Warszawa 2012. Autor broni tezy, że wiedzę na temat tego, co jest moralne, a co nie, można posiąść na drodze badań naukowych. Argumentuje przeciw relatywizmowi moralnemu. Stawia tezę o konieczności i nieuchronności ingerencji rozumu i empiryzmu naukowego w strefę emocji, do której należy szeroko rozumiana moralność. 
Ryszarda Stacha ${ }^{58}$ i Bogusława Pawłowskiego. ${ }^{59}$ Dla przykładu złota zasada moralności: „Nie czyń drugiemu, co tobie niemiłe” - wspólna tak wielu systemom etycznym - jest konstrukcją moralną, u której podstaw leży działanie neuronów lustrzanych (odkrytych w mózgu małp i człowieka). Neurony te odpowiadają najprawdopodobniej za empatię i współczucie, czyli możliwość postawienia się w sytuacji innego - czujemy to, co czują inni. Empatia wraz z teorią umysłu (odczytywaniem stanów mentalnych i interpretowaniem zachowań innych osobników), wykształconą dobrze już u pięciolatków, powstrzymują nas przed wyrządzaniem zła drugiemu, dzięki nim potrafimy wyobrazić sobie, jak cierpią inni, postrzegamy ich podmiotowo. Empatia hamuje też zachowania agresywne. Podobnie jest z moralną postawą altruisty, ma ona solidne podstawy w biologii. Ewolucja i teoria gier delikatnie faworyzują egoistę, ale jednocześnie zdolność do współpracy w grupie, kooperacja, altruizm krewniaczy, odwzajemniony i czysty to zachowania wzmacniane w procesie doboru naturalnego zwłaszcza wśród osobników żyjących w stadzie, w grupie. ${ }^{60}$ To tylko przykłady setek badań, które pokazują, że zachowania

58 R. S t a c h, Sumienie i mózg. O wewnętrznym regulatorze zachowań moralnych, Wydawnictwo Uniwersytetu Jagiellońskiego, Kraków 2012. Autor opisuje fenomen sumienia z perspektywy psychologii i neuronauki w odniesieniu do zachowań moralnych. Nie redukuje sumienia do biologii, ale wskazuje na biologiczne uwarunkowania funkcjonowania sumienia, poczynając od systemów emocjonalnych mózgu, przez mózgowe układy nagrody i kary, działania empatii, aż do neuronów lustrzanych. Sumienie ujmuje jako nagradzający lub karzący psychologiczny mechanizm adaptacyjny.

59 B. P aw ło w s k i, T. U l a n ow s k i, Nagi umyst. Dlaczego jesteśmy, jacy jesteśmy. Ludzka natura bez złudzeń, Wydawnictwo Agora, Warszawa 2016. Jest to wywiad z prof. Pawłowskim, biologiem i antropologiem, na temat biologicznych i ewolucyjnych podstaw wielu naszych zachowań i preferencji, także zachowań i preferencji moralnych. Jeden z wątków rozmowy wskazuje na ewolucyjne źródła naszych wyborów etycznych.

${ }^{60}$ Zob. szerzej M. R i d l e y, O pochodzeniu cnoty, tłum. M. K o r a s z e w s k a, Dom Wydawniczy Rebis, Poznań 2000; E.O. W i 1 s o n, Socjobiologia, tłum. M. S i e m i ń s k i, Zysk i S-ka, Poznań 2001. 
moralne poprzedzają wychowanie, rozumowanie, religię, poprzedzają prawo. Mają źródło w biologii ewolucyjnej, w nas samych.

Popularne powiedzenie przypisywane Dostojewskiemu: „Jeśli Boga nie ma, to wszystko wolno" ${ }^{61} \mathrm{w}$ tym świetle traci swą siłę. Nie jest tak, że bez religii człowiek pozbawiony jest zmysłu moralnego i norm etycznych. Moralność ukształtowała się wcześniej i niezależnie od wiary religijnej, w związku z czym religia będzie miała tu inne znaczenie niż jedynego gwaranta postępowania etycznego. Religia przede wszystkim będzie wzmacniać sądy i motywacje moralne oraz tworzyć normy sublimujące i przekraczające zachowania adaptacyjne. Na przykład lojalność wobec grupy może prowadzić do ksenofobii i zamknięcia na innych, wobec czego normy religijne otwarcie się na innych, bezinteresowność, miłość nieprzyjaciół itp. uszlachetniają i wzbogacają moralną stronę postępowania człowieka. Moralność osadzona jest w biologii, ale wsparta rozumem i religią może ją przekroczyć. Jedno z takich wyzwań dla etyki naturalnej zaproponowane jest w Piśmie Świętym.

\section{Czy Pismo Święte jest źródłem moralności?}

Papieska Komisja Biblijna w dokumencie Biblia a moralność. Biblijne korzenie postępowania chrześcijańskiego zauważa, że Biblia nie daje gotowych rozwiązań moralnych, zwłaszcza wobec dzisiejszych delikatnych problemów cywilizacyjnych, jak terroryzm, wojna, imigracja, podział dóbr, badania genetyczne, etyka życia seksualnego, szacunek dla zwierząt i zasobów naturalnych, etyka pracy, rodziny i życia wspólnotowego itd. To, czego możemy szukać w Biblii, to kryteria, których zastosowanie pozwala znaleźć odpowiednie

${ }^{61}$ W rzeczywistości w Braciach Karamazow Dostojewskiego pojawia się podobny, ale nie identyczny, cytat: „Jeżeli nie ma nieśmiertelności duszy, to i cnoty nie ma, a zatem wszystko jest dozwolone” („Нет бессмертия души, так нет и добродетели, значит, всё позволено"); zob. F. D o s t o j e w s k i, Bracia Karamazow. Powieść w czterech częściach z epilogiem, t. I-II, tłum. A. W a t, Państwowy Instytut Wydawniczy, Warszawa 1978, s. 104. 
rozwiązanie dla ludzkiego postępowania. Dwa podstawowe kryteria, wskazywane przez ten dokument to: zgodność z biblijną wizją istoty ludzkiej oraz zgodność z przykładem Jezusa. ${ }^{62}$

Jest to dojrzałe i mądre podejście do delikatnego zagadnienia moralności biblijnej. To, że dziś zgodnie potępiamy niewolnictwo, nie zawdzięczamy dosłownej lekturze Biblii, gdyż zarówno Pierwszy jak i Nowy Testament dopuszczają instytucję niewolnictwa (np. przypowieści Jezusa o niewolnikach czy listy św. Pawła, nie mówiąc już o Starym Testamencie). ${ }^{63}$ Do tego, że niewolnictwo jest złe, doszliśmy w toku historii drogą długich debat, sporów, rozpraw, a nawet wojen. Sublimując oceny moralne w tej sprawie, kierowaliśmy się nie literalnie rozumianym prawodawstwem Pisma Świętego, ale rozeznaniem rozumowym oraz ogólnymi kryteriami, które Biblia wyznacza w życiu wspólnotowym, a które wykraczają poza szczegółowe historyczne rozwiązania i uwikłania. Podobnie jest ze stosowaniem kary śmierci, społeczną pozycją kobiety i wieloma innymi kwestiami inaczej ocenianymi w Biblii, a inaczej dzisiaj. Papieska Komisja Biblijna, wymieniając we wspomnianym dokumencie zniesienie niewolnictwa, równość płci i wrażliwość na ochronę naturalnego dziedzictwa ludzkości, stwierdza: „Biblia nie podaje bezpośrednich i gotowych odpowiedzi zmierzających do rozwiązania tych lub innych problemów. Jednak jej orędzie o Bogu stwórcy wszystkiego i wszystkich, o odpowiedzialności ludzkiej za stworzenie, o godności każdej osoby ludzkiej, o szczególnej trosce o biednych - przygotowuje chrześcijan do aktywnego i owocnego uczestnictwa we wspólnym poszukiwaniu celem znalezienia odpowiednich rozwiązań

${ }^{62}$ Por. Papieska Komisja Biblijna, Biblia a moralność. Biblijne korzenie postępowania chrześcijańskiego, s. 12 (ze wstępu).

${ }^{63}$ W listach Pawłowych stosunek pan - niewolnik jest relatywizowany (zob. 1Kor 7,22-23; Kol 4,1), jednak nie z pobudek etycznych. Św. Paweł dopuszczał niewolnictwo. Na teksty z Pisma Świętego powoływało się Południe USA z dominującą gospodarką rolną nastawioną na produkcję bawełny, by zachować status quo niewolnictwa, co udało się niemal do początków XX w.; szerzej zob. I. B i e ż u ń s k a - M ałow is t, M. M ałow is t, Niewolnictwo, Czytelnik, Warszawa 1987, s. 387-404. 
powstających problemów" (nr 110). Uwaga znów kierowana jest raczej w stronę ogólnych kryteriów niż szczegółowych rozwiązań problemów moralnych.

Cytowany dokument PKB zaznacza, że „Biblia nie daje pełnych odpowiedzi" (nr 92) i gotowych, aktualnych rozwiązań kwestii moralnych współczesnego człowieka i że „dla przygotowania kwestii moralnych dotyczących tego rodzaju pytań trzeba uciec się do świateł refleksji teologicznej, rozumu i nauki" (tamże). Nie daje pełnych odpowiedzi, bo nie może ich dać. Biblia nie spadła z nieba. Została spisana przez ludzi, którzy w pełnym tego słowa znaczeniu są autorami napisanych tekstów. Księga napisana przez ludzi odzwierciedla ich sposób poznawania i opisywania otaczającej ich rzeczywistości. Dokument PKB ujmuje to słowami: ,Jest to zagadnienie delikatne, ze względu na to, że kanon Pisma Świętego przedstawia się jako złożona całość natchnionych tekstów: kolekcja ksiąg pochodzących od autorów i epok bardzo zróżnicowanych. (...) Z biegiem czasu ponadto jest się świadkiem różnorodnej ewolucji i udoskonalenia wrażliwości i motywacji moralnych" (tamże). To, co w chwili formułowania się orędzia biblijnego stanowiło zespół warunków kulturowych i historycznych, w następnych epokach staje się materiałem, wewnątrz którego trzeba odszyfrować samo orędzie, tak by ukazało się jego znaczenie w nowych warunkach.

Dobrym przykładem może być zmiana stanowiska Kościoła wobec kary śmierci. Trzej ostatni papieże zgodnie apelują o jej całkowite zniesienie, wbrew oczywistej dla Pisma Świętego Pierwszego i Nowego Testamentu jej akceptacji i wbrew liczącemu prawie dwa tysiąclecia tradycyjnemu nauczaniu Kościoła w tej sprawie. ${ }^{64}$ To podejście Magisterium potwierdza, że konkretne rozwiązania etyki biblijnej, nawet etyki Nowego Testamentu, nie są czymś absolutnym,

${ }^{64}$ Zob. szerzej T. Śl i p k o, Kara śmierci z teologicznego i filozoficznego punktu widzenia, WAM, Kraków 2000. Autor broni tradycyjnej nauki Kościoła o zgodności kary śmierci z porządkiem etycznym i o zasadności jej stosowania. Jednak apele papieży - zarówno św. Jana Pawła II (uwzględnione w KKK), Benedykta XVI i Franciszka - o całkowite zniesienie kary śmierci idą w przeciwnym kierunku. 
lecz ewoluują wraz z rozwojem moralnym społeczeństwa. Jezusowe Kazanie na górze (Mt 5) - doniosła reinterpretacja Dekalogu i prawa talionu - potwierdza konstatację antropologów i etyków, że moralność zmienia się wraz ze społeczeństwem i jego ewolucją kulturową. W ten sposób jesteśmy zachęcani do nieustannego badania i pogłębiania poszczególnych kwestii moralnych i szukania prawdy. Dokument PKB często mówi o „delikatnym procesie właściwego wyboru moralnego” czy o „złożoności kwestii etycznych” nie w celu ich relatywizacji, ale z głęboką świadomością wielowymiarowości różnych problemów moralnych współczesności. Nie wszystkie sprawy są na tyle oczywiste, by zacytować wyrwany z kontekstu werset biblijny i za jego pomocą potępić ludzkie wybory. W budowaniu etyki opartej na Biblii nie chodzi zatem o przytoczenie takiego czy innego cytatu celem wsparcia propozycji etyki filozoficznej (rozumowej). Chodzi bardziej o przeniknięcie ducha teologii moralnej teologią biblijną i kryteriami moralnymi, którymi się ona kieruje. Trzeba rozwijać teologię moralną (zakorzenioną w Biblii), a z drugiej strony filozofię moralną (zakorzenioną w racjonalnej, naukowej i filozoficznej refleksji), uwzględniając oba te źródła z zachowaniem harmonii między nimi (por. Gaudium et spes nr 46). Dynamika wzajemnej relacji między lumen rationis a lumen revelationis najlepiej służy poszukiwaniu rozwiązań dla współczesnych dylematów postępowania człowieka.

Co w takim razie z Dekalogiem, który stanowi, zdaniem wielu, ikonę etyki biblijnej i kartę moralności ogólnoludzkiej? Antropolodzy i egzegeci podważają globalną uniwersalność przykazań Dekalogu i charakter etyczny niektórych z nich. ${ }^{65}$ Relatywizują też jego wartość dla współczesnego człowieka. Nie gdzie indziej, jak w Dekalogu, kobieta jest wymieniona jako własność mężczyzny, do tego mniej cenna od domu: „Nie pożądaj domu bliźniego twego, nie pożądaj żony bliźniego swego, ani jego niewolnika, ani jego niewolnicy, ani jego wołu, ani jego osła, ani żadnej [innej] rzeczy, która jego jest" (Wj 20,17; w Pwt 5,21 kobieta jest wymieniona przed domem). Egzegeci zgadzają się dziś, że Dekalog stanowi odbicie prostego

65 Zob. np. F. d e W a a 1, Bonobo i ateista, s. 256. 
życia półkoczowniczych klanów, ${ }^{66}$ że jest skierowany do mężczyzn, ${ }^{67}$ że liczba dziesięć jest symboliczna (pochodzi nie $\mathrm{z}$ istnienia tylu dokładnie podstawowych reguł, lecz z jej statusu liczby oficjalnej i wartości mnemotechnicznej), ${ }^{68}$ że dwa pierwsze przykazania nie mają związku z etyką, ${ }^{69}$ a ostatnie: „Nie pożądaj” nie dotyczy myśli, lecz czynów zewnętrznych, i przede wszystkim, że Dekalog jest tak samo dokumentem moralnym, jak polityczno-religijną konstytucją kształtującego się narodu Hebrajczyków (podobnie jak nieco inny „dekalog" zawarty w Wj 34,10-26), ${ }^{70}$ nie ma zatem charakteru czysto etycznego. Dekalog koncentruje się na powstrzymaniu od zachowań społecznie i religijnie szkodliwych ( 8 z dziesięciu przykazań jest sformułowanych negatywnie), a więc na moralności zakazywania.

${ }^{66}$ Np. czasownik gnw oznaczał najprawdopodobniej nie tyle kradzież rzeczy materialnych, ile porwanie osoby, a czasownik hmd („,pragnąć”) nie tyle sferę myśli, ile czynności zewnętrznych.

${ }^{67}$ Wskazują na to treść poszczególnych przykazań Dekalogu (zob. np. Wj 20,10.15.17) oraz gramatyka: wszystkie formy zaimków i czasowników rozkazu są męskie (hebrajski ma zaimki drugiej osoby oraz imperatyw rodzaju żeńskiego).

${ }^{68}$ Dlatego pojawiają się w Dekalogu powtórzenia, a podział poszczególnych przykazań jest bardzo różny w różnych tradycjach religijnych. Przykazań w Dekalogu (odrębnych nakazów i zakazów) jest w istocie kilkanaście, ich podział na 10 jest wtórny i zależny od tradycji. Septuaginta, Talmud, współczesny judaizm, Kościół katolicki, prawosławny, protestantyzm, anglikanizm, luteranizm mają różne wersje podziału tekstu Dekalogu na 10 części. Dziesiątka, oprócz charakteru urzędowego i wartości mnemotechnicznej, to także istotne dla myślenia biblijnego złożenie trójki (przykazania dotyczące Boga) i siódemki (przykazana dotyczące drugiego człowieka). Obie liczby na swój sposób symbolizują pełnię i doskonałość.

${ }_{69}$ Bardziej radykalni myśliciele i egzegeci wskazują, że jedynie trzy z przykazań Dekalogu - czcij rodziców, nie zabijaj i nie kradnij- mają charakter czysto etyczny.

${ }^{70}$ Nie da się zrozumieć Dekalogu bez kontekstu, którym jest Wyjście-Przymierze, dwa fundacyjne wydarzenia historyczne narodu Izraela. Dekalog jest w nie wpisany jako konstytucja nowego ludu. Jest w pierwszej kolejności nie uniwersalistyczną kartą praw i obowiązków ludzkości, „deklaracją praw i obowiązków człowieka", ale konstytucją ludu Izraela na historycznym etapie jego początków i kształtowania swej tożsamości. Ma rolę narodowo- i wspólnototwórczą. 
To oczywiście nie wyczerpuje zadań karty etyki, która w wersji maksymalistycznej ma przecież wyjaśniać i stymulować ludzkie postępowanie w urzeczywistnianiu dobra (moralność wyrażona pozytywnie). Trudności w potraktowaniu Dekalogu jako uniwersalnej karty etyki jest więcej, dlatego cytowany dokument PKB o moralności proponuje nowe, pozytywne i uwspółcześnione odczytanie Dziesięciu przykazań (polecam w tym temacie nr 25-31). Na przykład przykazanie o czci szabatu interpretuje jako docenienie sakralnego wymiaru czasu oraz prawo do wolności praktyk religijnych, do dnia świętego i do odpoczynku (tamże).

Jako chrześcijanie nie przestrzegamy Dekalogu takiego, jaki zawarty jest w Starym Testamencie. Modyfikujemy przynajmniej dwa jego przykazania: zakaz czci obrazów i rzeźb (drugie/trzecie przykazanie) oraz nakaz świętowania soboty, szabatu (drugie/ trzecie/czwarte przykazanie - w zależności od tradycji). Co do innych przykazań, nasze rozumienie również różni się od literalnego. Przestrzegamy Dekalogu w sposób, w jaki Jezus nauczył nas go przestrzegać, zwłaszcza gdy dokonał jego reinterpretacji w Kazaniu na górze. Także współczesny judaizm szerzej postrzega zakres biblijnych micwot (,przykazań”). Wracamy więc to tego, o czym już mówiliśmy: moralność ewoluuje wraz z rozwojem społeczeństwa, jest to coś, co należy odkrywać, a nie coś co zostało nam dane raz na zawsze. Każde pokolenie kształtuje nowy obraz i wydobywa nową treść z Dekalogu. Ogólnoludzka wspólnota zasad moralnych (ich uniwersalizm) widoczna jest jedynie na bardzo podstawowym poziomie, jak „nie zadawaj bezsensownego cierpienia”, „karz łamiących normy". W Dekalogu taką podstawową wartością jest np. podkreślenie istotnej hierarchii celów, przykazania pojawiają się bowiem w porządku zmniejszającej się wagi (hierarchia zstępująca). Na pierwszym miejscu jest Bóg, wartości materialne na ostatnim. A wśród stosunków międzyludzkich najważniejsza jest rodzina, życie i stabilne małżeństwo. Nie tak łatwo promować te wartości, gdy ich hierarchia we współczesnym świecie zdaje się być odwrotna: najpierw człowiek, na końcu Bóg, a najważniejsze są dobra materialne (ekonomia i konsumpcjonizm). 
Etyka biblijna ma jedną zasadniczą i wyróżniającą ją cechę. Nie jest wyłożona dla niej samej, jako systematyczny, uporządkowany zbiór zasad moralnych, lecz - zarówno w Torze, jak i u proroków - zawsze traktuje się ją w relacji do faktu, że Bóg prowadzi Izraela przez historię. Moralność Starego Testamentu jest osadzona w wydarzeniu Wyjścia i Przymierza do tego stopnia, że niemal wszystkie zbiory moralno-prawne Izraela zostały retrospektywnie przypisane do tych wydarzeń (tworząc Pięcioksiąg). Pierwsze jest stwórcze i zbawcze działanie JHWH, natomiast podjęcie wezwań etycznych staje się odpowiedzią człowieka na łaskę stworzenia-wyzwolenia. Tę relacyjność moralności w stosunku do pierwszorzędnej pozycji Bożego daru widać w Dekalogu, w prawie, w nauczaniu proroków i u św. Pawła. Bóg Biblii nie objawia kodeksu, ale samego siebie. Życie moralne według Biblii jest przeżywane jako oddanie siebie w odpowiedzi na dar Boży (Rz 21,1), w relacji do Boga, gdyż w niej są osadzone wszystkie biblijne zalecenia moralne. Etyka Biblii jest zawsze druga. Pierwsza jest inicjatywa Boga, co przypomina preambuła Dekalogu: „Ja jestem Pan, twój Bóg, który cię wywiódł z ziemi egipskiej, z domu niewoli" (Wj 20,2). Po niej dopiero następują przykazania. Gdy św. Paweł zachęca chrześcijan, by postępowali w sposób godny swego powołania $(\mathrm{Ef} 4,1)$, to plasuje moralność właśnie w tej perspektywie: wielkodusznego odzewu na miłość Boga. Nowotestamentalne zasady działania moralnego nie są abstrakcyjnymi normami etyki, ale mają odniesienie do Chrystusa i osobowej relacji z Nim.

$$
* * *
$$

Ksiądz Michał Heller w jednym z wywiadów powiedział: „Teologia katolicka jest w głębokim kryzysie, ponieważ nie opiera się na żadnej filozofii, tylko na wizji świata, w której twierdzenia są oderwane od refleksji krytycznej. To wzmaga dysonans między nią a współczesną nauką. Między nimi nie tylko nie dochodzi do żadnych sporów polemicznych, ale wręcz narasta poczucie obcości 
i wzajemna ignorancja". ${ }^{71}$ Jako ludzie wierzący nie powinniśmy akceptować faktu, że o tej samej rzeczywistości nauka mówi jedno, a teologia drugie (np. na temat genezy śmierci). „Prawda nie może zaprzeczać prawdzie". Dobrze ustalone fakty naukowe nie powinny zaprzeczać prawdom wiary i odwrotnie. Włączanie do dyskursu teologicznego dobrze potwierdzonych i niespornych rezultatów badań naukowych jest elementem komunikacji i dialogu ze światem. Jest drogą hermeneutyczną teologii XXI w., drogą, która nie powinna stanowić jedynie reakcji obronnej i próby przetrwania w nowoczesnym społeczeństwie, ale winna być wysiłkiem nowego pozytywnego wyrażenia prawdy o Bogu i Jego dziele zbawczym. Nie chodzi o to, by teologia przyjmowała fakty naukowe z konieczności, będąc przypartą do muru i zagrożoną w swej wiarygodności, ale by podjęła je w sposób pozytywny, jako szansę lepszego wyrażenia prawdy o Bogu, który jest Deus semper major. Teologia w spotkaniu z inną wiedzą staje przed zadaniem, aby pozostać na tropie Boga, który jest zawsze większy.

Teologia jako racjonalna refleksja nad objawieniem i doświadczeniem wiary zakłada jakiś obraz świata. Ten obraz jest ciągle uaktualniany, głównie dzięki wiedzy naukowej. Wydaje się, że należałoby tak wyrażać prawdy teologiczne, by nie wchodzić w kolizję z dobrze uzasadnionymi tezami naukowymi, jak np. teoria ewolucji, a jednocześnie ujmować świat z głębszej i szerszej perspektywy, niż czynią to nauki przyrodnicze. Dobrym przykładem jest teologia stworzenia, która nie schodzi na poziom fizycznego konkretu i nie utożsamia aktu stwórczego z Wielkim Wybuchem, lecz widzi w stwarzaniu stałą ontologiczną zależność wszystkiego od Boga. Bóg nie stwarza obok praw natury czy wbrew nim, ale wewnątrz nich, np. wewnątrz ewolucji biologicznej. To podejście sprawia, że to, co z punktu widzenia nauk przyrodniczych jawi się jako przypadek i ślepa siła, z punktu widzenia wiary jest Bożą opatrznością. Ów alternatywny

${ }^{71}$ D. W o d e c k a, Światło we Wszechświecie. Wywiad z ks. prof. Michałem Hellerem, http://wyborcza.pl/magazyn/1,132056,13654729,Swiatlo_we_wszechswiecie. html (dostęp: 20 II 2016). 
język teologii wnosi istotnie nową informację o świecie, której nauki przyrodnicze nie są w stanie zidentyfikować: świat stworzony został z miłości, więc jest sensowny. ${ }^{72}$

Takie samo zadanie staje przed teologią biblijną. Rozpoznanie faktu ewolucji świata i człowieka oraz wiele kolejnych odkryć, które ono spowodowało, mają ogromne konsekwencje antropologiczne i teologiczne. Mam wrażenie, że teologia biblijna jeszcze nie do końca je przerobiła (notabene jest to problem nie tylko teologii, ale wielu nauk humanistycznych). Fakt ewolucji świata ze wszystkimi jego implikacjami powinien skłonić teologię do przemyślenia swej doktryny i nowego jej wyrażenia, jak przystało na jej anzelmiańską definicję: fides quaerens intellectum, wiara, która poszukuje zrozumienia. Święty Anzelm, autor tego sformułowania, w swych rozważaniach o Bogu starał się, by nie traktować powagi Pisma Świętego jako antytetycznej wobec intelektu i w poszukiwaniach duchowych skupić się w pierwszej kolejności na głosie samego rozumu (sola ratio), by następnie zintegrować go $\mathrm{z}$ wiarą i danymi objawienia. Podobną drogą świadoma refleksja religijna w dialogu ze światem porusza się dzisiaj. Dotyczy ona przede wszystkim uzgodnienia chrześcijańskiej antropologii z obrazem człowieka, jaki wyłania się z ustaleń nauki. Artykuł ten jest zaledwie jakimś wstępem i zaproszeniem do dyskusji na ten temat.

\section{Marcin MAJEWSKI}

Słowa kluczowe: Biblia, nauka, nauki przyrodnicze, dusza, mózg, umysł, antropologia, grzech pierworodny, ewolucja, dowody na istnienie Boga, cuda, źródła moralności, Dekalog

Keywords: Bible, science, soul, brain, mind, anthropology, original sin, evolution, evidences for the existence of God, miracles, source of morality, Ten Commandments

72 A. S p o r n i a k, Dziedzictwo Kaina, https://www.naukaireligia.pl/dziedzictwo-kaina-29632 (dostęp: 20 II 2016). 
The Bible and Science. Seven reflections inspired by the thought of Prof. Michael Heller

\section{Summary}

The aim of the article is to show some areas where the results of exegesis and biblical theology should be confronted with the latest discoveries of science on the world, nature, evolution, the human being, the brain, free will, psychology and morality. The author compares, shows difficulties arising from, and attempts to reconcile Christian anthropology with the image of man that emerges from well-established scientific truths. This paper is an introduction and an invitation to a discussion on this topic. 